\title{
Reviews
}

\section{Insulin granule dynamics in pancreatic beta cells}

\author{
P. Rorsman ${ }^{1,2}$, E. Renström ${ }^{2}$ \\ ${ }^{1}$ The Oxford Centre for Diabetes, Endocrinology and Metabolism, Churchill Hospital, Headington, Oxford \\ 2 Department of Physiological Sciences, Lund University, Lund, Sweden
}

\begin{abstract}
Glucose-induced insulin secretion in response to a step increase in blood glucose concentrations follows a biphasic time course consisting of a rapid and transient first phase followed by a slowly developing and sustained second phase. Because Type 2 diabetes involves defects of insulin secretion, manifested as a loss of first phase and a reduction of second phase, it is important to understand the cellular mechanisms underlying biphasic insulin secretion. Insulin release involves the packaging of insulin in small (diameter $\approx 0.3 \mu \mathrm{m}$ ) secretory granules, the trafficking of these granules to the plasma membrane, the exocytotic fusion of the granules with the plasma membrane and eventually the retrieval of the secreted membranes by endocytosis. Until recently, studies on insulin secretion have been confined to the appearance of insulin in the extracellular space and the cellular events preceding exocytosis have been
\end{abstract}

inaccessible to more detailed analysis. Evidence from a variety of secretory tissues, including pancreatic islet cells suggests, however, that the secretory granules can be functionally divided into distinct pools that are distinguished by their release competence and/or proximity to the plasma membrane. The introduction of fluorescent proteins that can be targeted to the secretory granules, in combination with the advent of new techniques that allow real-time imaging of granule trafficking in living cells (granule dynamics), has led to an explosion of our knowledge of the pre-exocytotic and post-exocytotic processes in the beta cell. Here we discuss these observations in relation to previous functional and ultra-structural data as well as the secretory defects of Type 2 diabetes. [Diabetologia (2003) 46:1029-1045]

Keywords Pancreatic islets, insulin, secretory granules, exocytosis, diabetes, confocal microscopy.
Received: 20 January 2003 / Revised: 12 May 2003

Published online: 17 July 2003

(C) Springer-Verlag 2003

Corresponding author: Dr. P. Rorsman, Department of Physiological Sciences, Lund University, BMC F11, 22184 Lund, Sweden

E-mail: patrik.rorsman@mphy.lu.se

Abbreviations: $\left[\mathrm{Ca}^{2+}\right]_{\mathrm{i}}$, Free cytoplasmic $\mathrm{Ca}^{2+}$-concentration; EGFP, enhanced GFP; fF, femtofarad $\left(10^{-15} \mathrm{~F}\right)$; GFP, green fluorescent protein; $\mathrm{K}_{\mathrm{ATP}}$-channel, ATP-regulated $\mathrm{K}^{+}$-channel; $\mathrm{LDCV}$, large dense-core vesicle; $\mathrm{ms}$, millisecond; $\mathrm{mV}$, millivolt; RRP, readily releasable pool of granules; SNARE, soluble $N$-ethylmaleimide-sensitive factor attachment protein receptors.

\section{Introduction}

Insulin is the body's only blood glucose-lowering hormone and is secreted by the pancreatic beta cells of the islets of Langerhans. After its synthesis in the endoplasmic reticulum, insulin is processed to its biologically active form and stored in the secretory granules pending its release. Ultra-structural studies have shown that a single beta cell contains more than 10000 secretory granules $[1,2]$. The quantitatively most important route for the release of insulin into the islet interstitium is by regulated $\mathrm{Ca}^{2+}$-dependent exocytosis of the secretory granules $[3,4,5,6]$. Traditionally, insulin secretion has been measured biochemically using, for example, radioimmunoassays. Such experiments report the amount of insulin being secreted 
but the temporal resolution is fairly low and the regulation of the steps that precede release cannot be elucidated. During the last decade, several new techniques have emerged to study insulin secretion that allow the release and the pre-exocytotic as well as post-exocytotic events to be monitored at high temporal resolution down to the single-granule $[7,8,9,10]$. We attempt to summarize the insights that have been derived by applying these new methods to the pancreatic beta cell and discuss these data in relation to systemic regulation of insulin secretion and diabetes.

\section{Electrical activity couples increase in the blood glucose concentration to insulin secretion}

An increase in the extracellular glucose concentration leads to the induction of electrical activity [11, 12]. Over the physiological range of glucose concentrations, this electrical activity consists of oscillations in membrane potential between depolarised plateaux, on which bursts of action potentials are superimposed, separated by repolarised electrically silent intervals. The periods of electrical activity are accompanied by changes in the cytoplasmic $\mathrm{Ca}^{2+}$-concentration $\left(\left[\mathrm{Ca}^{2+}\right]_{\mathrm{i}}\right)[13]$, which in turn drive pulsatile insulin secretion (Fig. 1C, [14, 15, 16]). Glucose produces a concentration-dependent increase in electrical activity and at glucose concentrations over $20 \mathrm{mmol} / \mathrm{l}$, uninterrupted action potential firing is observed [11, 12]. Thus, at least in the intact islet, every beta cell responds to glucose in a graded fashion. Although glucose also exerts an effect on downstream steps in the secretory process, it is not able to elicit insulin release if electrical activity and the accompanying $\mathrm{Ca}^{2+}$-influx are prevented. Thus, the progressive increase in beta cell electrical activity is a key element in the series of reactions culminating in glucose-induced insulin secretion.

Patch-clamp experiments have established that although beta cells contain 10 to 20 different ion channel proteins (each present in 100-5000 copies per beta cell) [12], two types of ion channels are particularly important for the initiation of insulin secretion: ATP-regulated $\mathrm{K}^{+}$-channels $\left(\mathrm{K}_{\mathrm{ATP}}\right.$-channels) and voltage-gated $\mathrm{Ca}^{2+}$ channels (Fig. 1A). The $\mathrm{K}_{\mathrm{ATP}}$-channels are spontaneously active at low glucose and the efflux of positively charged $\mathrm{K}^{+}$through these channels generates an excess of negative charges inside the cell and thereby accounts for the negative membrane potential of the unstimulated beta cell (Fig. 1B). Glucose enters the beta cell via the glut2 transporter and the ensuing metabolic breakdown of the sugar leads to the generation of ATP at the expense of ADP. This in turn results in closure of the $\mathrm{K}_{\mathrm{ATP}}$-channels, membrane depolarisation and initiation of electrical activity. The effect of glucose on $\mathrm{K}_{\mathrm{ATP}^{-}}$ channel activity is concentration-dependent with an $\mathrm{EC}_{50}$-value in intact islets of approximately $5 \mathrm{mmol} / \mathrm{l}$ [17]. At insulin-releasing glucose concentrations, the
A
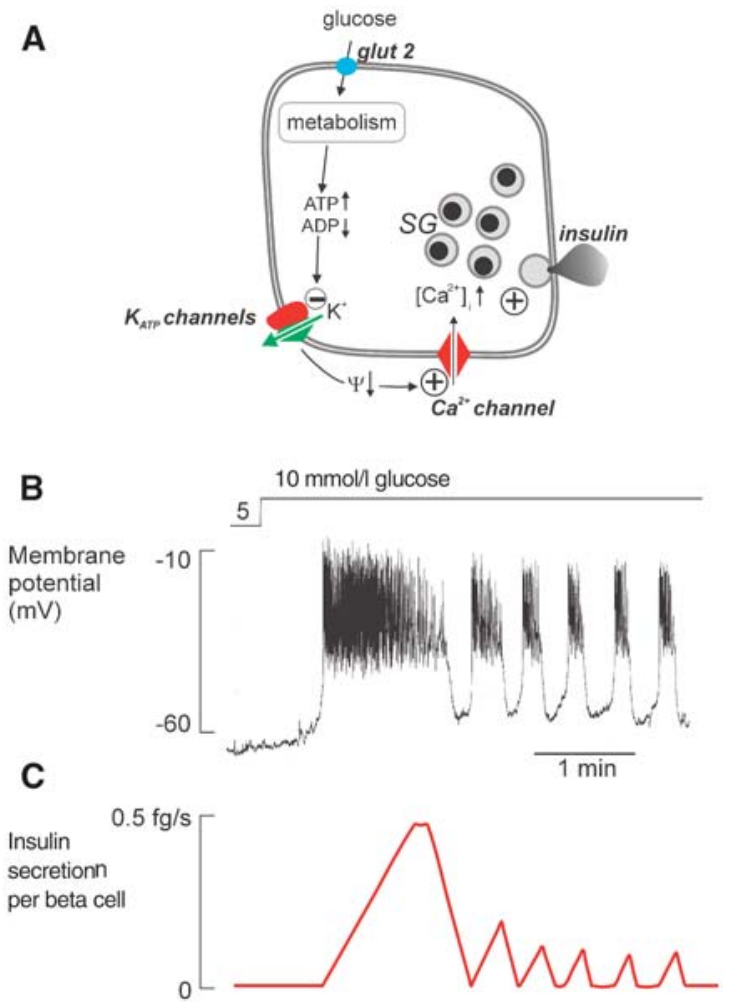

Fig. 1. A Stimulus-secretion coupling in pancreatic beta cell. Abbreviations used: glut2, glucose transporter; $\mathrm{K}_{\mathrm{ATP}}$ channels, ATP-regulated $\mathrm{K}^{+}$-channels; $\Psi$, membrane potential; $\mathrm{SG}$, secretory granules. The + and - signs denote stimulation and inhibition, respectively, whereas the arrows $(\uparrow, \downarrow)$ indicate an increase or decrease of the indicated parameter. B Glucose-induced electrical activity recorded from a beta cell in an intact pancreatic islet when the glucose concentration is raised from $5 \mathrm{mmol} / \mathrm{l}$ to $10 \mathrm{mmol} / \mathrm{l}$ (as indicated by staircase above membrane potential trace). The periods of electrical activity result in pulsatile insulin secretion illustrated schematically in $\mathbf{C}$

$\mathrm{K}_{\text {ATP-channels are almost completely inhibited. Action }}$ potential firing in the beta cell is dependent on the opening of voltage-gated $\mathrm{Ca}^{2+}$-channels and the resulting increase in $\left[\mathrm{Ca}^{2+}\right]_{\mathrm{i}}$ then triggers exocytosis of the insulin granules [5, 18]. Pancreatic beta cells contain three to four distinct types of $\mathrm{Ca}^{2+}$-channels. However, the Ltype $\mathrm{Ca}^{2+}$-channels are particularly important for exocytosis of the insulin-containing granules $[19,20]$.

\section{Quantitative aspects on insulin secretion}

As first demonstrated by Grodsky et al. more than 30 years ago [21], insulin secretion in response to glucose stimulation exhibits a characteristic biphasic pattern and consists of a rapidly initiated and transient first phase followed by a sustained second phase during which secretion continues at a somewhat lower rate but still enhanced with respect to the pre-stimulatory control (Fig. 2). Only a fraction of the beta cell insulin content is released during stimulation. First and second 
A

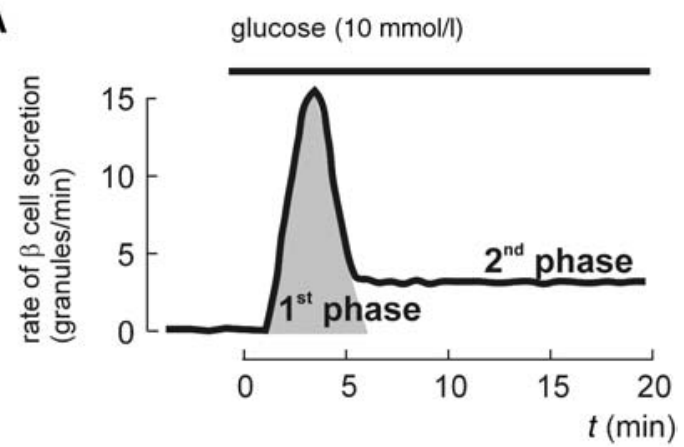

B

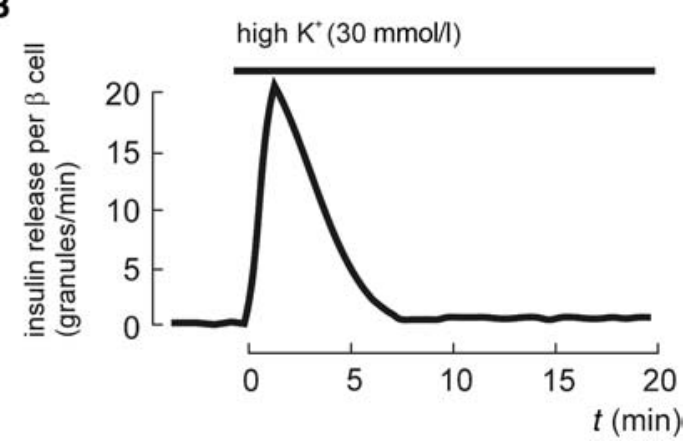

Fig. 2. A Schematic of insulin secretion elicited by an increase of the extracellular glucose concentration to $\geq 10 \mathrm{mmol} / \mathrm{l}$. Insulin secretion is triggered with a delay of $\sim 1 \mathrm{~min}$ (the time needed for glucose to be metabolised) and then follows a biphasic time course. Rates of secretion are taken from [22, 23]. B Schematic of insulin secretion elicited by an increase of the extracellular $\mathrm{K}^{+}$-concentration to $30 \mathrm{mmol} / \mathrm{l}$. Note that the response is monophasic and that there is no delay. The number of granules undergoing exocytosis per beta cell and minute was estimated from the release data of [77] assuming that every secretory granule contains 1.6 amol [37] of insulin and that a typical mouse islet consists of 1000 beta cells

phase insulin secretion in mouse islets have accordingly been reported to amount to $0.14 \% / \mathrm{min}$ and $0.05 \% / \mathrm{min}$, respectively [22]. Given that every beta cell contains about 10000 granules, these release rates correspond to approximately 15 and 5 granules per minute and beta cell [23]. Approximating first-phase insulin secretion to a triangle, we can thus estimate that the total number of granules undergoing exocytosis during first phase (lasting $5-10 \mathrm{~min}$ ) is limited to 40 to 80 granules per beta cell. Whereas the ability of glucose to elicit first phase insulin secretion is shared by other stimuli resulting in membrane depolarisation (such as sulphonylureas or an increase in extracellular $\mathrm{K}^{+}$), only fuel secretagogues are capable of initiating second-phase insulin secretion (compare Fig. 2A and Fig. 2B; see reviews $[24,25])$.

\section{Novel methods to study release}

Traditional biochemical assays of exocytosis [such as radioimmunoassay (RIA) or enzyme linked immuno- sorbent assay (ELISA)] are characterized by a limited temporal and quantitative resolution. At best, secretion can be monitored in single islets (containing $\approx 1000$ cells) with a sample interval longer than $1 \mathrm{~s}$ [26]. Although this as such represents a considerable accomplishment, the elucidation of the cell biology of islet-hormone secretion requires an even higher temporal resolution.

During the last decade, several new methods have emerged that allow exocytosis and intracellular granule trafficking preceding exocytosis to be studied in individual cells. Capacitance measurements [7, 27] monitor the changes in cell surface area that occur when secretory granules fuse with the plasma membrane (Fig. 3A). This technique exploits the fact that cell capacitance, which can be easily measured by electrophysiological techniques, is proportionally related to the cell surface area (i.e. $\mathrm{C}=\varepsilon^{*} \mathrm{~A}$ where $\mathrm{C}$ stands for cell capacitance, $\mathrm{A}$ is the surface area and $\varepsilon$ the specific membrane capacitance). Given that the specific capacitance is $0.9 \mathrm{fF} / \mu \mathrm{m}^{2}$ [28] and that granules have spherical geometry with a diameter of $0.36 \mu \mathrm{m}$ [2], exocytosis of a single vesicle can be estimated to produce a capacitance increase of $3.6 \mathrm{fF}$. Capacitance measurements have several advantages over traditional biochemical assays of secretion. These include (i) very high time resolution $(\approx 1 \mathrm{~ms})$; (ii) single cells are studied; (iii) access to the cytosol is provided via the recording electrode; (iv) secretion in the entire cell is monitored at the same time; and (v) the measurements are conveniently combined with several other complementary methods for single-cell detection of exocytosis. However, there are also a number of limitations of the technique. For example, capacitance measurements report the net change in cell-surface area and do not discriminate between exoand concomitant endocytosis. They likewise do not distinguish between exocytosis of insulin-containing secretory granules and other processes that can increase cell-surface area such as fusion of small GABA-containing synaptic-like microvesicles (SLMVs) that are known to be present in the beta cell [29, 30]. There is also concern that exocytosis of organelles other than secretory vesicles can give rise to a capacitance increase [31]. In addition, an increase in cell capacitance only indicates that membrane fusion has occurred, not necessarily that the hormonal content has actually been released.

Carbon fibre amperometry affords the possibility to determine the release of granule content after membrane fusion. Certain oxidizable substances, like catecholamines and serotonin, can be detected electrochemically by carbon microfibres, thus allowing the release of individual secretory vesicles to be resolved at high temporal resolution [32]. A release event typically gives rise to a transient current spike (Fig. 3B). This technique has been successfully applied to beta cells in which the granules have preloaded with sero- 
A
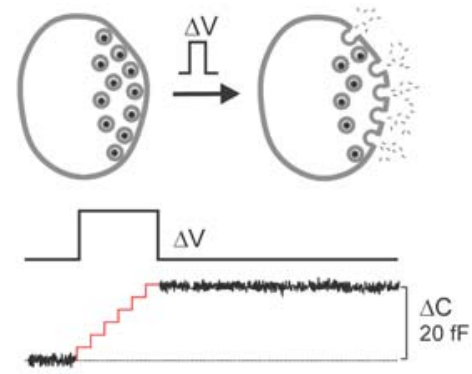

B
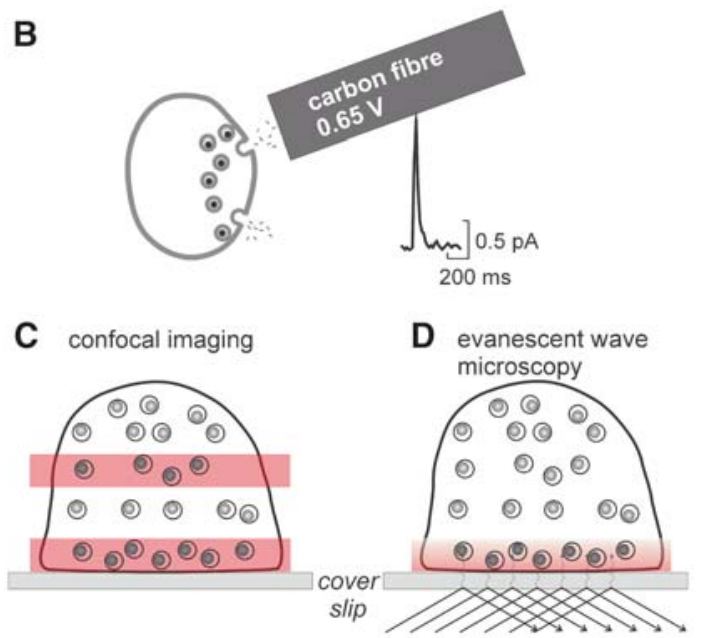

Fig. 3A-D. Techniques to monitor exocytosis as well as intracellular granule dynamics. A Capacitance measurements. Exocytosis can be triggered by a brief depolarisation $(\Delta \mathrm{V})$. The influx of $\mathrm{Ca}^{2+}$ triggered by the voltage pulse leads to the fusion of (five) secretory granules. For technical reasons, the recording is usually interrupted during the depolarisation and the net increase in cell capacitance $(\Delta C)$ that occurred during the pulse is shown (illustrated schematically by the red trace). B Carbon fibre amperometry. A carbon fibre connected to an amplifier is placed in the vicinity of the cell. Exocytosis can be detected as amperometric current spikes that develop when the substance released (serotonin) is oxidized by the high voltage ( $>0.6$ Volt) applied to the carbon fibre (lower right). C Confocal imaging. Movements of granules containing a fluorophore (like EGFP) monitored in different segments of the cell (a central plane and the region near the part of the plasma membrane adhering to the cover-slip highlighted in red) by scanning different optical planes of the cell. D In evanescent wave microscopy, illumination of a specimen is restricted to a layer above the coverslip (red area), only a few hundred nanometers thick, thus facilitating the study of events taking place in the immediate vicinity of the plasma membrane

tonin $[33,34,35,36]$. The carbon fibre technique has subsequently been improved to detect insulin itself [37]. Analysis of the amperometric currents suggests that a single secretory granule in a human beta cell contains 1.7 amol of insulin, which equates to an intragranular insulin concentration of $118 \mathrm{mmol} / \mathrm{l}$. The corresponding values in rat granules were $1.6 \mathrm{amol}$ and $74 \mathrm{mmol} / \mathrm{l}$. Results obtained with serotonin and insulin amperometry are in general agreement but the insulin spikes are somewhat broader than those representing serotonin release. Interestingly, the release of serotonin could be dissociated from that of insulin by lowering extracellular $\mathrm{pH}$ from 7.4 to 6.4; whereas serotonin release was still detectable at the lower $\mathrm{pH}$, insulin secretion was abolished [38]. Taken together the latter observations suggest that although membrane fusion can occur at $\mathrm{pH} 6.4$, a $\mathrm{pH}$ gradient is necessary to drive release and that dissociation of the $\mathrm{Zn}$-insulin complex limits the rate of hormone release. This scenario is suggested by analogy to the release of catecholamines from chromaffin cells $[39,40]$.

All the methods discussed above share the weakness of more traditional secretion assays in only reporting that exocytosis has occurred but provide no information about the pre- and post-exocytotic events. This type of information can only be gained by the optical monitoring of individual secretory vesicles before, during and after exocytosis. Despite the small size of the granules, this is in fact possible by engineering chimaeras between green fluorescent protein (GFP) and proteins normally sorted to the secretory granules. The granules rendered fluorescent by transfection of cells with the GFP-constructs can then be visualized using confocal microscopy to study both the release process as well as pre- and post-exocytotic granule movements [41]. Confocal microscopy (Fig. 3C) allows fluorescence in thin sections of the cell $(\sim 0.5 \mu \mathrm{m})$ to be imaged with little contribution from neighbouring planes. Another possibility is to view the granules using evanescent wave microscopy [9]. The advantage of the latter technique is that only the fluorophore within a few $100 \mathrm{~nm}$ from the upper surface of the coverslip is reached by the excitation light. This means that the emitted fluorescence exclusively reflects the dynamics of granules situated within the immediate vicinity of the plasma membrane, avoiding signals from, in this context, irrelevant locations deeper within the cell. Several variants of GFP with distinct spectral properties are now available and it is thus possible to label the granule membrane and the cargo with different constructs and to simultaneously monitor the fluorescence of both compartments in the same vesicle. This provides the means to study the subsequent retrieval of the secreted membranes by endocytosis that must occur following exocytosis.

\section{Molecular machinery of exocytosis in beta cells}

A vast body of molecular and physiological data accumulated over the past years have led to a unifying model for regulated exocytosis. Because this is a central aspect of granule dynamics, we briefly review the salient features of regulated exocytosis. Interested readers are referred to more extensive accounts elsewhere for more exhaustive descriptions [42, 43, 44]. A group of proteins referred to as SNARE proteins play a critical role in membrane fusion. These proteins associate to form complexes that attach to the mem- 
A

B

C

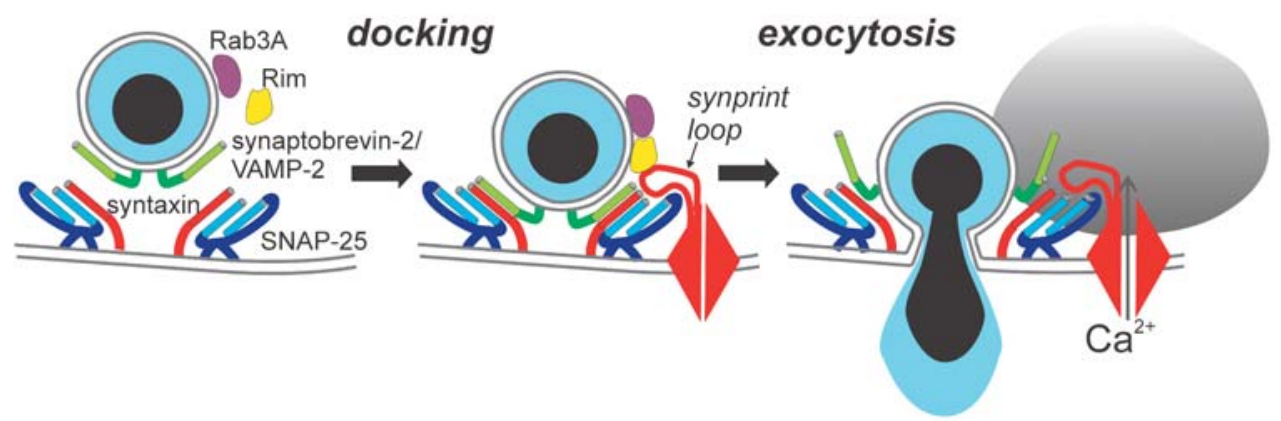

Fig. 4A-C. SNARE proteins, granule docking and exocytosis. During docking (A), the granule approaches the plasma membrane and the vesicular protein synaptobrevin/VAMP-2 pairs with their plasma membrane binding partners syntaxin and SNAP-25, giving rise to a tight complex that tethers the granule to the plasma membrane and, in the beta cell $[19,75]$, to the $\mathrm{Ca}^{2+}$-channel $(\mathbf{B})$. Fusion of the two membranes then occurs following a localised increase in $\left[\mathrm{Ca}^{2+}\right]_{\mathrm{i}}$ that occurs during the opening of the $\mathrm{Ca}^{2+}$-channel $(\mathbf{C})$. Also indicated in $\mathbf{A}, \mathbf{B}$ are the GTP-binding protein Rab3A and its interaction partner Rim. Rim also possesses the ability to associate with the $\mathrm{Ca}^{2+}$ channel subunit $\alpha 1_{C}$ and the SNARE-protein SNAP-25 (illustrated in B) as well as and $\mathrm{Ca}^{2+}$-sensor synaptotagmin (not shown)

branes that will eventually fuse and include the plasma membrane proteinssyntaxin andSNAP-25 and vesicular proteinsynaptobrevin (also referred to as VAMP) (Fig. 4). A current model postulates that the SNARE proteins facilitate exocytosis by bringing the vesicle membrane in close contact with the plasma membrane in a way analogous to a zipper [42]. The conformational changes that occur during this process are believed to provide the energy required to produce membrane fusion. The SNARE proteins are insufficient to account for the rapid $\mathrm{Ca}^{2+}$-dependent exocytosis that represents a hallmark of secretory cells. Synaptotagmin currently represents the favourite candidate $\mathrm{Ca}^{2+}$-sensor in synaptic vesicle fusion $[45,46$, 47]. A family of thirteen different synaptotagmin has been identified. They typically contain two $\mathrm{Ca}^{2+}$-binding sites: $\mathrm{C} 2 \mathrm{~A}$ and $\mathrm{C} 2 \mathrm{~B}$. In the presence of phospholipids, synaptotagmin I and II exhibit $\mathrm{EC}_{50}$-values for $\mathrm{Ca}^{2+}$-binding of 10 to $20 \mu \mathrm{mol} / \mathrm{l}$, whereas synaptotagmin III and VII exhibit 5 to 20 times higher affinities (i.e. $\sim 1 \mu \mathrm{mol} / \mathrm{l}$ ) [47]. Synaptotagmins I and II are essential for synaptic vesicle (SV) exocytosis but release of peptide-containing large dense core vesicles (LDCV) does not require these proteins [47]. Thus, distinct synaptotagmins are likely to control $\mathrm{Ca}^{2+}$-dependent exocytosis of LDCV and SV as well as secretion in different tissues.

Exocytosis in beta cells conforms to the general picture of SNARE-regulated exocytosis. Insulinsecreting cell lines possess the full complement of SNARE proteins that are either very similar or even identical to those participating in synaptic vesicle re- lease [48, 49] and fulfil the same functions. The SNARE proteins also seem to be important for exocytosis in primary beta cells. Using permeabilised mouse beta cells, intracellular application of a monoclonal antibody directed against syntaxin inhibited insulin secretion $[50,51]$. There remains uncertainty about the identity of the $\mathrm{Ca}^{2+}$-sensor for exocytosis in beta cells. Although synaptotagmins I and II were initially identified in insulin-secreting cell lines and participate in $\mathrm{Ca}^{2+}$-dependent exocytosis in these cells [52], primary beta cells do not express either of these synaptotagmins. Synaptotagmin III could play a role [53] but doubts have been raised as to the specificity of the antibody used in these experiments [47] and the most recent evidence rather implicates synaptotagmins $\mathrm{V}$ or VII [54]. The involvement of a synaptotagmin with a higher $\mathrm{Ca}^{2+}$-affinity would account for the observation that intracellular dialysis with $\mathrm{Ca}^{2+}$-EGTA buffers with free $\mathrm{Ca}^{2+}$-concentrations as low as $\geq 0.2 \mu \mathrm{mol} / 1$ is capable of evoking exocytosis $[55,56]$.

A family of small GTP-binding Rab proteins is also involved in the molecular control of regulated exocytosis. Several isoforms of the Rab proteins have been described but the most extensively studied member of this family is Rab3A [57]. This protein cycles between a vesicle-associated GTP-binding form and a cytoplasmic state after exocytosis and hydrolysis of GTP into GDP. In neurones, Rab3a exerts an inhibitory action on neurotransmission by limiting the number of synaptic vesicles released in response to an increase in synaptic $\left[\mathrm{Ca}^{2+}\right]_{\mathrm{i}}[58]$. In beta cells, Rab3A locates to the cytoplasmic face of the secretory granules. Its functional role in insulin secretion is controversial but most reports are consistent with the idea that it functions as a "brake", thus limiting the release of insulin $[59,60]$ in a way similar to its role in the synaptic transmission. Recently it was reported, however, that Rab3A null mice exhibit glucose intolerance and decreased firstphase glucose-evoked insulin secretion [61], an effect that was attributed to impaired replenishment of release-competent pool of granules (RRP). These seemingly contradictory findings might reflect that several regulatory proteins interact with Rab3A, each exerting a variety of distinct actions on the beta cell processes linked to the control of insulin release [60]. For exam- 
A

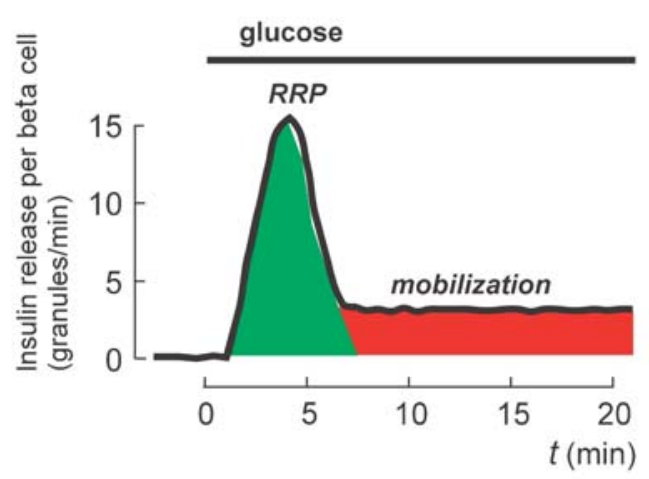

B

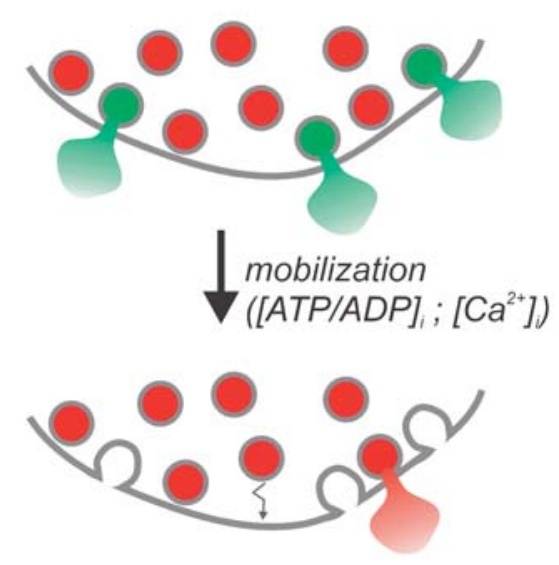

Fig. 5A, B. Granule pools and biphasic insulin secretion. A Schematic of glucose-induced insulin secretion. B Beta cell contains (at least) two pools of secretory granules that differ with regard to release competence. A limited pool of granules $(<5 \%)$ are immediately available for release, the readily releasable pool of granules (RRP, green granules). Most granules (>95\%) initially belong to a reserve pool (red granules) and must undergo a series of preparatory reactions in order to gain release comptence (mobilization). Hypothetically, release of RRP granules accounts for first-phase secretion and its end marks the depletion of this pool. The area under the curve describing first-phase release is equivalent to the release of $\approx 40$ granules (15 granules/min*6 min/2). The subsequent supply of new granules for release by mobilization (influenced by the intracellular ATP, ADP and $\left[\mathrm{Ca}^{2+}\right]_{\mathrm{i}}$ ) accounts for second-phase insulin secretion

ple, both Rim (Rab3-interacting molecule) and its isoform Rim2 are present in beta cells and are involved in glucose-stimulated insulin release [62]. RIM interacts with a plethora of proteins and seems to function as a protein scaffold [63, 64]. For example, binding of Rim2 to the cAMP-sensor cAMP-GEFII transmits the PKA-independent portion of cAMP-mediated stimulation of insulin secretion [65]. Surprisingly, this effect is lost in SUR1 null mice (i.e. mice lacking the sulphonylurea receptor protein SUR1, one of the subunits of the $\mathrm{K}_{\mathrm{ATP}}$-channel) indicating that the role of the latter protein extends beyond being a $\mathrm{K}_{\mathrm{ATP}}$-channel subunit and is also involved in the control of secretion [66]. Clearly, the role of Rab3A and its interaction with various effector proteins remain poorly understood and merits further studies.

\section{Cell biological models for phasic hormone release}

Biochemical experiments as well as analyses of the time course of the increase in cell capacitance in a variety of endocrine cell types, including pancreatic islet cells, have led to the proposal that the secretory vesicles exist in distinct functional pools and that sequential release of these pools gives rise to kinetically sep- arable components of exocytosis. Typically, only a fraction of the granules (1-5\%) belong to a readily releasable pool (RRP) [27]. Granules belonging to this pool are release-competent and can undergo exocytosis without any further modification after stimulation. Release of such granules is believed to underlie a rapid component of release (Fig. 5A). The majority of granules (95-99\%) belong to a non-releasable pool that must undergo a series of ATP-, $\mathrm{Ca}^{2+}$, time- and temperature-dependent reactions (collectively referred to as mobilization or priming) to gain release competence (Fig. 5B). The latter process involves the formation of SNARE complexes $[67,68]$ but could clearly also entail additional maturation reactions leading to an increased probability of release.

It is tempting to explain biphasic insulin secretion in terms of functionally distinct pools of granules. Indeed, this possibility was considered more than 30 years ago by Grodsky who proposed an insulin storage-limited mathematical model to describe the kinetics of secretion in beta cells $[69,70]$. By analogy to the situation in chromaffin cells, beta cell exocytosis elicited by a step increase in $\left[\mathrm{Ca}^{2+}\right]_{\mathrm{i}}$ is biphasic and consists of a rapid component (reflecting release of RRP) and a subsequent much slower sustained component. In beta cells, RRP has been estimated to contain 20 to 100 granules $(0.2-1 \%)$ depending on the experimental conditions [71, 72]. The size of RRP thus estimated is in reasonable agreement with the $\sim 40$ granules that can be estimated to undergo exocytosis per beta cell during first-phase insulin secretion (Fig. 5A) [73]. Therefore a substantial part of firstphase insulin secretion could be attributable to exocytosis of RRP-granules. We explain the fact that firstphase insulin secretion is only transient and that the secretory rate returns towards the baseline as the usedependent depletion of RRP. Once this pool of granules has been emptied, exocytosis proceeds at a (usually) much lower rate, presumably reflecting the low rate at which new granules are supplied for release by priming of reserve granules (Fig. 5A,B). 
The hypothesis that the different phases of glucoseinduced insulin secretion can be understood in terms of release of functionally distinct populations of secretory granules is underpinned by the differential metabolic requirements of first- and second-phase insulin secretion. Accordingly, capacitance measurements have shown that exocytosis of RRP granules does not require ATP-hydrolysis, whereas its refilling is highly ATP-dependent. These metabolic requirements resemble those of first- and second-phase insulin secretion (Fig. 2A,B). Moreover, agents that stimulate granule mobilization and increase the size of RRP exert similar effects of first- and second-phase insulin secretion. For example, compounds that increase cyclic AMP (e.g. the adenylate cyclase activator forskolin and the incretin hormone GLP-1) accelerate granule mobilization and increase the size of RRP in mouse beta cells fivefold (see Fig. 4 in [71]). These effects nicely correlate with reported fourfold to sixfold enhancement of first- and second-phase insulin secretion in mouse islets [74].

\section{SNARE proteins direct $\mathrm{Ca}^{2+}$-entry to RRP granules}

The SNARE proteins not only play a role in the fusion of the granules with the plasma membrane, they also ensure that $\mathrm{Ca}^{2+}$-entry is restricted to the areas of the plasma membrane in close contact with the secretory granules. The intracellular loop connecting the second and the third homologous domains of the L-type $\mathrm{Ca}^{2+}$ channel (L-loop) binds to syntaxin, SNAP-25 and synaptotagmin and tethers the $\mathrm{Ca}^{2+}$-channel to the secretory granule. The length of the L-loop suggests that the distance between the inner mouth of the $\mathrm{Ca}^{2+}$ channel and the secretory granules is less than $10 \mathrm{~nm}$ [75]. Thanks to this arrangement, the release-competent granules (=RRP) are exposed to the high (exocytotic) levels of $\mathrm{Ca}^{2+}$ occurring just beneath the inner mouth of the $\mathrm{Ca}^{2+}$-channel. Exocytosis will therefore proceed in an essentially all-or-none fashion depending on whether the $\mathrm{Ca}^{2+}$-channel is open or not. We point out that the beta-cell action potential is brief (only $50 \mathrm{~ms}$ ) and that glucose-induced beta-cell electrical activity increases sigmoidally with increasing glucose concentrations [76].

\section{Ultrastructural correlates of biphasic insulin secretion}

The first detailed ultrastructural studies of the pancreatic beta cell were carried out 30 years ago [1] and revealed that an individual beta cell contains about 13,000 insulin granules. Given the possibility that first- and second-phase insulin secretion reflects the release of RRP followed by mobilization of new granules from the reserve pool, it is important to compare

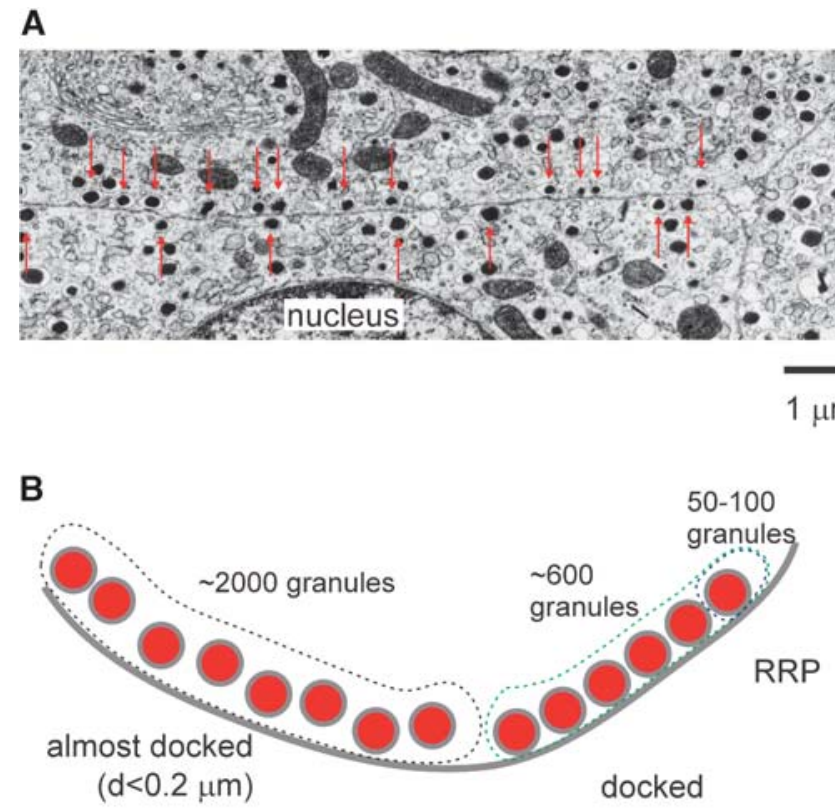

Fig. 6A, B. Ultrastructural correlates of biphasic insulin secretion. A Electron micrograph through a beta cell in an intact mouse islet. The arrows indicate granules that seem to be docked with the plasma membrane. B Summary of ultra-structural analyses of mouse beta cell. Of the 10,000 granules in the beta cell, $\sim 600$ are docked with the plasma membrane and an additional 2000 granules reside within $0.2 \mu \mathrm{m}$ from the plasma membrane (almost docked). The readily releasable pool (RRP), defined by functional measurements, is assumed to represent a small subset (50-100 granules, depending on the experimental conditions) of the docked pool

the functional and ultrastructural correlates of insulin secretion. We have reported that mouse beta cells contain $\sim 10,000$ granules per cell [2]. Interestingly, as many as $\approx 5 \%$ of the granules are docked below the membrane (i.e. appear to be in direct contact with the plasma membrane) and a further 2000 granules reside within less than one granule diameter from the plasma membrane (Fig. 6).

The idea that first phase insulin secretion principally reflects release of docked granules was tested by subjecting the beta cell to intense stimulation using $75 \mathrm{mmol} / 1$ extracellular $\mathrm{K}^{+}$in the absence of glucose for $15 \mathrm{~min}$ [2]. This stimulation, which is believed to elicit a first-phase-like secretory response, was associated with a $30 \%$ reduction in the number of docked granules but had no effect on granule distribution in the remainder of the cell. A subsequent second period of stimulation with high $\mathrm{K}^{+}$failed to evoke insulin secretion when the experiment was done in the absence of glucose. However, when glucose was present at $5 \mathrm{mmol} / \mathrm{l}$, the secretory response to the second period of stimulation was comparable to that elicited by the first stimulation [2]. The depletion of the docked pool (i.e. a release of 200 granules) established by electron microscopy is larger than that expected to occur if only granules belonging to RRP, as defined by the capac- 
itance measurements, were released. It is possible that this discrepancy reflects a pool of granules that are "nearly RRP", i.e. granules that can attain release competence without access to extra metabolic energy. Indeed, published measurements of $\mathrm{K}^{+}$-induced insulin secretion reveal a tail of insulin secretion after the initial first phase that might reflect such a process (Fig. 4B in [77]).

Three important conclusions can be drawn from these experiments: (i) first-phase insulin secretion involves exocytosis of RRP, which constitutes a subset of the docked pool of granules; (ii) RRP comprises a distinct and limited population of granules and once this pool has been depleted, secretion stops; and (iii) metabolic energy is required for the refilling of RRP from the reserve pool. These conclusions reinforce those previously reached by others using alternative techniques [78]. Because of the accumulation of granules below the plasma membrane, replenishment of RRP can be envisaged to occur without any (extensive) movements of granules within the cell. The docked granules alone (650 per mouse beta cell) are sufficient for $2 \mathrm{~h}$ of glucose-stimulated insulin secretion (the initial first phase of 50 granules $+120 \mathrm{~min}$ of secretion at 5 granules/min) [23]. Needless to say, the fact that recruitment is not required for sustained secretion does not mean that it does not occur. Recent data obtained using real-time single-granule imaging in Min6-cells indicate that late secretion is due to exocytosis of granules that have just arrived at the plasma membrane [79]. Also of note, electron microscopy only provides a snapshot of the situation in the beta cell at the time of fixation and it is therefore not possible to conclude with certainty that the "docked" granules are really physically attached to the plasma membrane and not merely situated just beneath the plasma membrane because of random granule movements.

\section{Capacitance measurements on isolated beta cells suggest very high rates of secretion}

Capacitance measurements on isolated cells have indicted that exocytosis in the beta cell can proceed at much higher rates than suggested by insulin release measurements $[19,75]$. Thus, the peak of exocytosis attained within 20 milliseconds (ms) after onset of depolarisation corresponds to a rate of 18000 granules per min. The latter rate is approximately 1000 -fold higher than that indicated by the insulin release measurements (Fig. 2B). An important difference between the two methods to monitor secretion is that whereas capacitance measurements have so far exclusively been done on isolated beta cells, insulin release is traditionally determined using intact pancreatic islets. When capacitance measurements are instead applied to beta cells in the intact islets, the maximum rate of exocytosis is reduced by $85 \%$ (Göpel and Rorsman, unpublished). The reason for the abnormally high rate of exocytosis in single beta cells is not clear but it might be the consequence of the extensive rearrangement of cell architecture likely to take place after cell isolation, plating on a non-biological surface and tissue culture. Alternatively, the lower rates of capacitance increase seen in the intact islet are a consequence of inhibitory paracrine mechanisms. Such an effect can be exerted, for example, by the inhibitory hormone somatostatin that is secreted by neighbouring $\delta$-cells within the intact pancreatic islet and reduces $\mathrm{Ca}^{2+}$-dependent exocytosis by about $80 \%$ [80]. However, even if allowance is made for this, there remains a 150-fold discrepancy between the speed of exocytosis suggested by capacitance recordings and insulin secretion measurements.

\section{Emptying of granules is much slower than membrane fusion}

Capacitance measurements only report that membrane fusion has occurred, which can not necessarily be equated to the release of the compound(s) contained in the granules (Fig. 7). Carbon fibre amperometry has been applied to beta cells that have been loaded with serotonin [33, 34, 35, 36, 56, 81]. Serotonin accumulates in the halo of the secretory granules [82] and it should accordingly be released together with insulin after exocytotic fusion of the granules with the plasma membrane. Surprisingly, there is a substantial delay between the capacitance increase and the appearance of serotonin in the extracellular space. Whereas the rate of capacitance increase peaks after about $20 \mathrm{~ms}$ after the onset of stimulation, release of serotonin is hardly detectable at all during the initial $100 \mathrm{~ms}$ [35, 36]. Analyses of capacitance flickers indicate that an increase in cell capacitance is first detectable when the diameter of the fusion pore ranges between 1 and $2 \mathrm{~nm}[83,84,85]$. The molecular dimensions of serotonin are $0.7 \times 0.7 \times 0.2 \mathrm{~nm}$. Thus, the size of serotonin is not negligible compared to the width of the fusion pore and the exit of serotonin could therefore be spatially constrained just after opening of the fusion pore. This could contribute to the delay between membrane fusion (seen as a capacitance increase) and the extracellular appearance of the indoleamine. If this already applies to fairly small molecules like serotonin, then slow expansion of the fusion pore is likely to exert an even greater hindrance on the exit of larger molecules like insulin.

The recent advent of fluorescent proteins that can be tagged to cellular proteins destined for exocytotic release has provided valuable insight into the parameters determining the release kinetics of the peptide cargo. Using this approach, both insulin itself or other granule proteins have been tagged with various variants of GFP [41, 79, 86, 87, 88, 89]. Although the mo- 
A

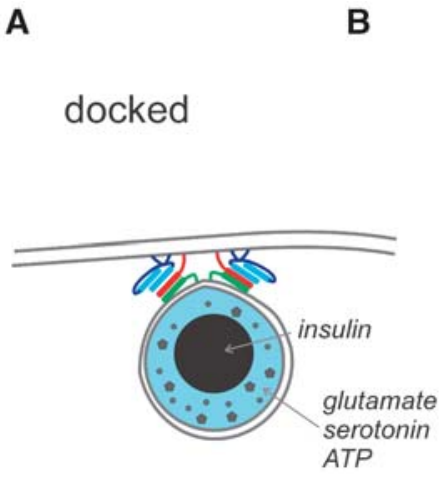

Fig. 7A-C. Dissociation between granule fusion and evacuation of granule interior. A Docked beta cell granule. Hexameric insulin stored in crystalline form centrally. The halo of the granule contains low molecular weight substances like nucleotides (ATP, ADP), serotonin and glutamate. B During exocytosis, a narrow ( $\leq 1 \mathrm{~nm}$ ) connection (fusion pore) between the granule interior and the extracellular space is transiently (and reversibly) established. Low molecular weight substances, but not insulin, can exit via the fusion pore. $\mathbf{C}$ When the fusion pore has dilated sufficiently $(\mathrm{d}>12 \mathrm{~nm}$; cf. [84]), the granule collapses into the plasma membrane and insulin is released

lecular weight of GFP is 4 to 5 times larger than that of insulin, the physical dimensions of the proteins are not vastly different $(5.1 \mathrm{~nm} \times 3.7 \mathrm{~nm} \times 3.5 \mathrm{~nm}$ for EGFP vs $3.2 \mathrm{~nm} \times 3 \mathrm{~nm} \times 2.5 \mathrm{~nm}$ for the insulin monomer) [88]. Thus, the disappearance of EGFP from the granules can be expected to approximate the exit of insulin into the extracellular space.

We have monitored insulin granule dynamics in Ins1-cells using enhanced GFP (EGFP) tagged to granular protein islet amyloid poylypeptide (IAPP) [88]. This construct targets correctly to the lumen of secretory granules and, applying confocal imaging, it is possible to monitor the emptying of individual secretory granules in real time as well as the events preceding exocytosis. Gratifyingly, many of the concepts based on electron microscopy and the functional studies could then be verified. For example, the existence of a docked pool of immobile granules in direct contact with the plasma membrane in living cells could be directly shown. Whereas most granules approaching the membrane and all the granules in the cytoplasm undergo quite extensive movements ( $\geq 1 \mu \mathrm{m} / 10 \mathrm{~s}$ ) [88, 90 ], about $25 \%$ of the granules situated within the first $1 \mu \mathrm{m}$ beneath the plasma membrane were essentially immobile [88]. By the combination of single-vesicle imaging and patch-clamp recordings, it was possible to compare the temporal relationship between membrane fusion (monitored as an increase in cell capacitance) and cargo release (disappearance of EGFP fluorescence). Consistent with the observations made by amperometry, there was a long delay (up to $12 \mathrm{~s}$ !) between membrane fusion and cargo release with an average of about $2 \mathrm{~s}$. A similar latency between the establishment of the fusion pore and release of insulin
C

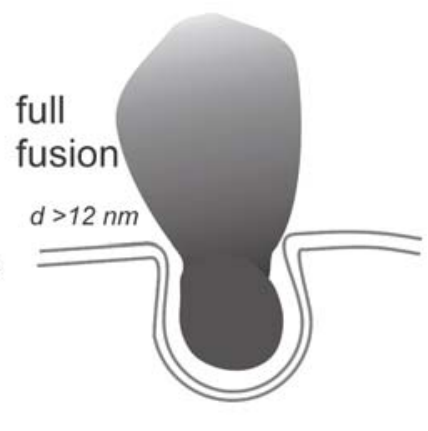

was recently derived by measurements of fusion pore dynamics in mouse beta cells using extracellular markers with different molecular dimensions [84]. The slow release of the peptide cargo could result from its slow dissociation from the intragranular matrix, the properties of which in the insulin granule remain poorly defined. Such a scenario is suggested by analogy to the release of catecholamines from chromaffin cells, where ion exchange via the fusion pore leads to matrix swelling that provides the tension which eventually leads to the opening of an aperture between the granule lumen and the extracellular space large enough to allow complete granule emptying [40, 91]. Irrespective of the underlying reason, these observations suggest that release of high molecular weight substances (such as insulin) is about 25-fold slower than the time course of capacitance increase [88]. This delay probably accounts for much of the 150 -fold discrepancy between the release rates suggested by capacitance measurements and insulin release measurements that persists even when allowance is made for the different release kinetics of isolated beta cells and cells in the intact islet. The remaining tenfold difference we attribute to the voltage-dependence of exocytosis which is only $10 \%$ at $-30 \mathrm{mV}$ (the membrane potential attained in the presence of $30 \mathrm{mmol} / \mathrm{l} \mathrm{K} \mathrm{K}^{+}$) of that attained at zero $\mathrm{mV}$ (the voltage during the voltage-clamp depolarisations used to trigger exocytosis in the capacitance measurements) [18].

As membrane fusion can be temporally separated from cargo release it provides the beta cell with an interesting mechanism for secretory plasticity. Recent data obtained using Min6-cells transfected with chimaeric constructs of both synaptotagmin/pHluorin and NPY/venus (to report the $\mathrm{pH}$ change that occurs after opening of the fusion pore and cargo release, respectively) suggest that only a fraction of the exocytotic events (detected as granular $\mathrm{pH}$ equilibration and increase in pHluorin fluorescence) is associated with cargo release (seen as the disappearance of venus) [92]. It is well established that the granules contain many substances in addition to insulin. Some of these are of low molecular weight. Examples of the latter group include $\mathrm{Zn}^{2+}$, ATP, $\mathrm{Ca}^{2+}$, glutamate, serotonin and dopamine $[82,93,94,95,96]$. It is conceivable that these substances can pass through the fusion pore 
before complete fusion. If the fusion pore can open transiently without proceeding into complete fusion, low molecular weight substances could be released independently of insulin from the granules and possibly exert a regulatory function within the islet (Fig. 7B).

\section{Recovery of RRP doesnot require granule translocation}

Following emptying of RRP (failure of continued stimulation to elicit secretion), the exocytotic capacity gradually recovers but about $1.5 \mathrm{~min}$ is required for complete replenishment of RRP [72]. Thus, refilling of RRP is in full operation already during first-phase insulin secretion and this could account for the fact that glucose-induced insulin secretion never returns to the baseline but remains stimulated with respect to the prestimulatory level throughout the glucose challenge. The restoration of RRP requires access to metabolic energy $[2,97]$. The EGFP-tagged granules allowed us to determine whether the recovery of RRP requires physical translocation of the granules or if modification of granules already in place is sufficient (compare Fig. 6). Simultaneous confocal single-granule imaging and capacitance measurements in Ins1 cells showed that at the time RRP was functionally depleted by intense stimulation, only $13 \%$ of the docked (immobile) granules had undergone exocytosis [88]. This reinforces the concept, based on comparison of electron microscopy with capacitance measurements made in primary mouse beta cells [2], that RRP represents a subset of the docked pool (20-100 granules depending on the experimental conditions; i.e. $3-15 \%$ of the 600 docked granules) and that docking precedes the final preparation of the granules for release (priming). The docked granules that were not released during the first train (i.e. $>85 \%$ ) clearly represent a large reserve pool of granules. The exocytotic capacity of the cell recovered almost completely within less than 2 min without the arrival of "new" granules at the plasma membrane. Rather, renewed stimulation of secretion was associated with the release of granules that were present already during the initial period of stimulation but then failed to undergo exocytosis. These observations suggest that: (i) rapid release (first-phase insulin secretion?) is principally attributable to exocytosis of the docked and primed secretory granules; and (ii) late secretion (second phase?) can, at least in the short run and in Ins1 cells, be accounted for by priming of granules already situated below the plasma membrane.

\section{Intracellular pre-exocytotic granule movements}

Although depletion of RRP in the short-term can be compensated for by mobilization of granules situated below the plasma membrane, it is clear that sustained insulin secretion will ultimately require the physical translocation of granules to the release zones. Whereas many of the granules situated immediately below the membrane are immobile, imaging granule dynamics at high temporal resolution ( $\geq 10$ images per second) in the centre of the cell shows that some of the granules undergo extensive movements [86, 88, 90, 98]. These can broadly be divided into two classes: (i) rapid directed jumps (saltatory movements [86, 90]); and (ii) slower, seemingly undirected movements (diffusional movements). The saltatory movements had a mean velocity of about $0.6 \mu \mathrm{m} / \mathrm{s}$. The number of saltatory events increased during glucose stimulation [86] and in permeabilised Ins 1 cells, the latter effect could be mimicked by increasing the intracellular ATP concentration [90]. It has been proposed that the effects of glucose and ATP on granule movements are mediated by the motor protein kinesin. Kinesins are motor proteins that use ATP hydrolysis to move cargoes (e.g. secretory granules) along the microtubules. Transfection of Ins1- and Min6cells with a dominant negative kinesin heavy chain mutant abolished rapid granule movements and sustained insulin secretion [90]. Further support to the idea that saltatory movements and the cytoskeleton are important for the maintenance of RRP and the secretory capacity, disruption of the microtubule network using vindesine or vincristine (Fig. 8A,C) impairs both the initial and sustained components of exocytosis (monitored as depolarisation-evoked capacitance increases; Fig. 8B,D) by more than 50\% and reduced first and second phases of glucose-induced insulin secretion in mouse pancreatic islets to a similar extent [99]. These effects on secretion correlated with a $85 \%$ reduction in the number of saltatory events (Ivarsson and Renström, in preparation).

\section{How do granules become available for release?}

The evidence summarized in the preceding sections suggests that many of the granules (85-97\%) situated at the plasma membrane are not immediately available for release but that they can quickly gain release competence in a process that does not require any extensive movements of the granules. In this section we consider mechanisms that influence the capacity of a granule to undergo exocytosis.

One of the popular concepts in current beta-cell biology is the ability of glucose to exert both triggering and amplifying effects on insulin secretion [25, 100]. The glucose-induced closure of the $\mathrm{K}_{\mathrm{ATP}}$-channels with resultant membrane depolarisation, opening of voltage-gated $\mathrm{Ca}^{2+}$-channels and release of insulin represents the triggering action of glucose. In addition, glucose also exerts an additional amplifying effect, which is not dependent on $\mathrm{K}_{\mathrm{ATP}}$-channel inhibition and that becomes apparent when the beta cell is 
A

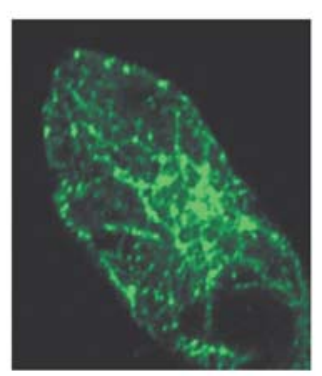

C

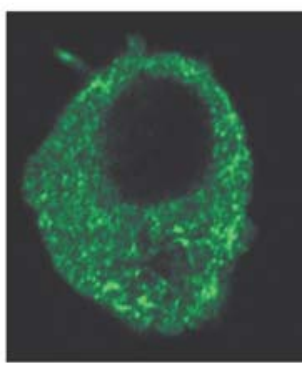

B

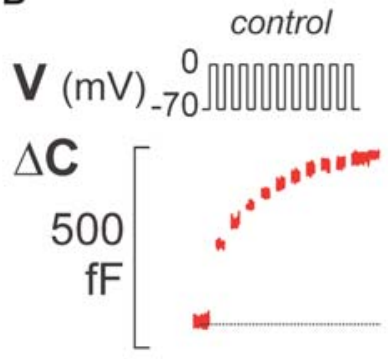

A

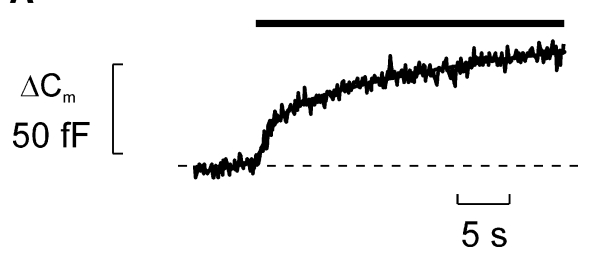

B

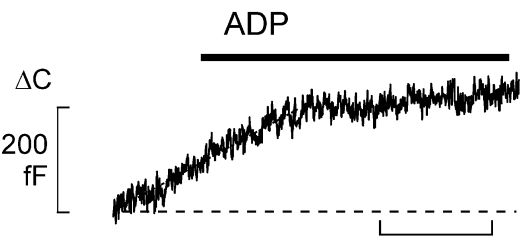

$5 \mathrm{~s}$

Fig. 9A, B. Rapid regulation of exocytosis by ATP and ADP. A Stimulation of exocytosis by ATP. Increase in cell capacitance $\left(\Delta \mathrm{C}_{\mathrm{m}}\right)$ after photorelease of $1 \mathrm{mmol} / \mathrm{l}$ ATP (horizontal bar) from a caged precursor. Data from [97]. B Inhibition of exocytosis by stepwise increase in cytoplasmic ADP (bar). Data from [75]

the amplifying effect of glucose develops quickly upon stimulation [25] and with the same time course as the inhibition of the $\mathrm{K}_{\mathrm{ATP}}$-channels (e.g. monitored using ${ }^{86} \mathrm{Rb}$-fluxes; review [105]), there seems to be little need to postulate additional coupling factors. It is pertinent that the sub-membrane concentrations of ADP and ATP apparently change considerably during glucose stimulation as witnessed by the ability of the sugar to inhibit the $\mathrm{K}_{\mathrm{ATP}}$-channels, the ATP- and ADPsensor nature itself has perfected.

Measurements of ATP and ADP concentrations in rat beta cells have shown that Mg-ADP decreases from $0.6 \mathrm{mmol} / \mathrm{l}$ to $0.3 \mathrm{mmol} / \mathrm{l}$, whereas $\mathrm{Mg}$-ATP increases from $2 \mathrm{mmol} / \mathrm{l}$ to $4 \mathrm{mmol} / \mathrm{l}$ when glucose is increased from 1 to more than $10 \mathrm{mmol} / \mathrm{l}$ (average intracellular concentrations of ATP and ADP estimated assuming an intracellular volume of $\sim 1 \mathrm{pl}$ ) [106]. Varying the ATP concentration in the physiological range $(\geq 1 \mathrm{mmol} / \mathrm{l})$ has no effect on exocytosis. By contrast, the above range of ADP-concentrations correlate exactly with that where ADP exerts its strongest effect on secretion [107]. Of note, the ADP and ATP levels given above refer to the total concentrations (i.e. the $\mathrm{Mg}^{2+}$-salts of the nucleotides) and the free concentrations are considerably lower. Using enzyme cycling methodology, the free ADP concentration was estimated to be as low as $40 \mu \mathrm{mol} / \mathrm{l}$ [108]. However, this should not distract from the fact that varying the total ADP concentration within a physiological range in a semi-intact beta cell modulates exocytosis in a way reminiscent of that produced by glucose. Collectively, these observations indicate that ATP represents a permissive factor and that the metabolic regulation of insulin secretion by glucose (the amplifying action) is instead mediated by changes in the ADP-concentration in a way analogous to the control of the $\mathrm{K}_{\mathrm{ATP}}$-channels (Fig. 10). 


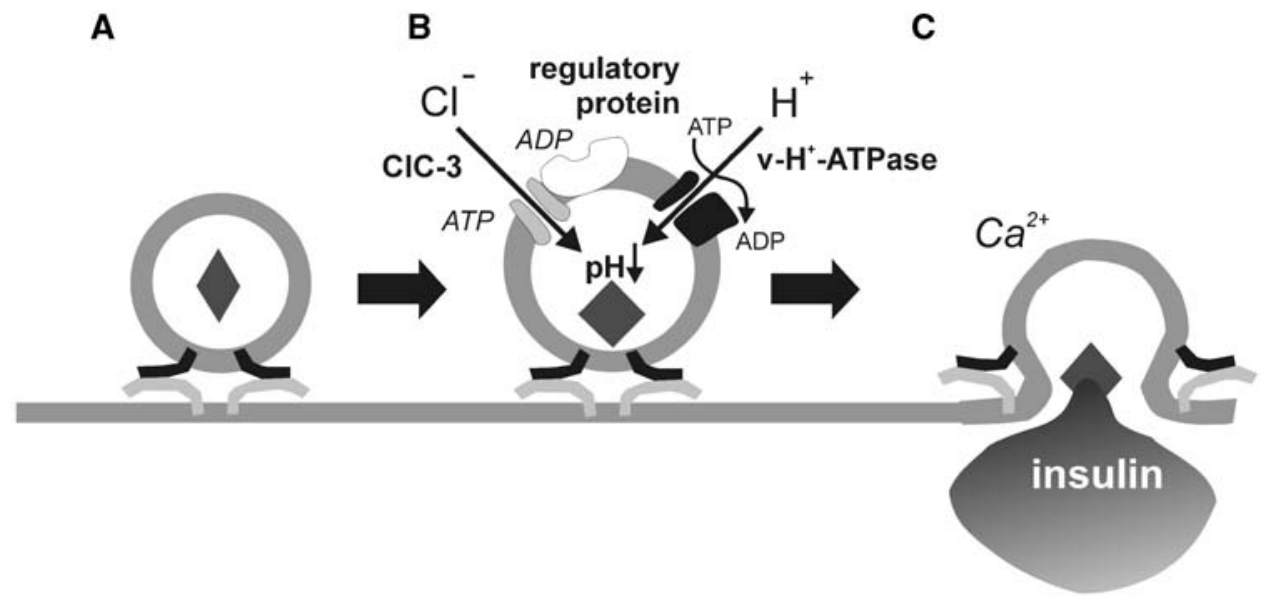

Fig. 10A-C. Metabolic regulation of granule priming. A Docked granule (pairing of SNARE-proteins; cf. Fig. 4) that have not yet attained release competence. $\mathbf{B ~ C l}^{-}$uptake through an ion channel complex comprised of $\mathrm{ClC} 3 \mathrm{Cl}^{-}$channels and a regulatory subunit determines the extent of granular acidification by providing the counter-ion required to allow continuous $\mathrm{H}^{+}$pumping by a V-type $\mathrm{H}^{+}$-ATPase. The activity of the $\mathrm{ClC} 3-$ channels is inhibited by high concentrations of ADP. C Once granular acidification has occurred, granules can undergo exocytosis whenever $\left[\mathrm{Ca}^{2+}\right]_{\mathrm{i}}$ increases to exocytotic levels. (see [109] for details)

How can changes in ADP and ATP translate into an increased or decreased release competence of the secretory granules? There is some evidence implicating intragranular acidification in the priming of the betacell granules for release [109]. Thus, the ability of the granules to prime is dependent on the simultaneous operation of a V-type $\mathrm{H}^{+}$-ATPase and $\mathrm{ClC} 3 \mathrm{Cl}^{-}$-channels. The $\mathrm{Cl}^{-}$-channel activity provides a shunt conductance, which (partially) neutralizes the large electrical field that would otherwise develop as consequence of $\mathrm{H}^{+}$-pumping (Fig. 10) [110]. Granules that had already been primed remained releasable even after inhibition of the $\mathrm{H}^{+}$-ATPase and/or $\mathrm{ClC} 3$ channels but the refilling of RRP was prevented $[75,109]$. Intracellular application of ADP in the presence of a high concentration of ATP prevents granular acidification and priming. It was therefore proposed that $\mathrm{ADP}$, via regulation of the $\mathrm{ClC} 3$-channel, could provide the metabolic switch that determines the "releasability" of the granules. Potentially, the $\mathrm{ClC} 3$-channel therefore represents a potential novel molecular target for new antidiabetic substances.

\section{Endocytosis}

Once granules have undergone exocytosis, the secreted granular membrane must be recaptured by endocytosis. Measurements of cell capacitance have indicated the presence of a rapid (time constant $10 \mathrm{~s}$ ) and slow (time constant $100 \mathrm{~s}$ ) type of endocytosis [83]. Whereas the fast type of endocytosis appeared particularly important after weak stimulation, the slow type predominated after large exocytotic increases in membrane surface area resulting from intense stimulation. In most cases, endocytosis exactly compensated for the increase in cell surface area that occurs during stimulation of exocytosis.

Three types of endocytosis have been postulated to take place after exocytosis $[111,112]$. In the first type, popularly referred to as "kiss-and-run", the granule content is released through the fusion pore that transiently and reversibly opens during exocytosis. In this mode of exo-/endocytosis, the fusion pore could close even before emptying of the granule interior has been completed and without mixing of the granule membrane with the plasma membrane (Fig. 11A). Alternatively, the granule membrane is integrated into the plasma membrane (complete fusion) and the extra membrane is subsequently recaptured by conventional clathrin-mediated endocytosis (Fig. 11C). There is an intermediate "kiss-and-run"-like mode of exo-/endocytosis ("semifusion"; Fig. 11B) that involves the establishment of a large opening between the granule lumen and the extracellular space but where the granule remains structurally intact [113]. Similar observations have been made in Min6-cells [41]. Our own measurements in Ins1-cells indicate that "semifusion" accounts for $90 \%$ of the release events. Granules undergoing this form of exocytosis are subsequently retrieved within less than $10 \mathrm{~s}$. Complete fusion occurs in only $10 \%$ of the cases (Obermüller, Lindqvist, Jovasiene, Rorsman and Barg, submitted). By analogy with findings in retinal bipolar neurones [114], perhaps the slow and rapid components of capacitanceincrease described above represent kiss-and-run and conventional endocytosis, respectively.

\section{Significance to diabetes}

The selective loss of first phase insulin secretion is an early feature of Type 2 diabetes [115]. The possible relationship between first- and second-phase insulin secretion and distinct, functionally defined, popula- 


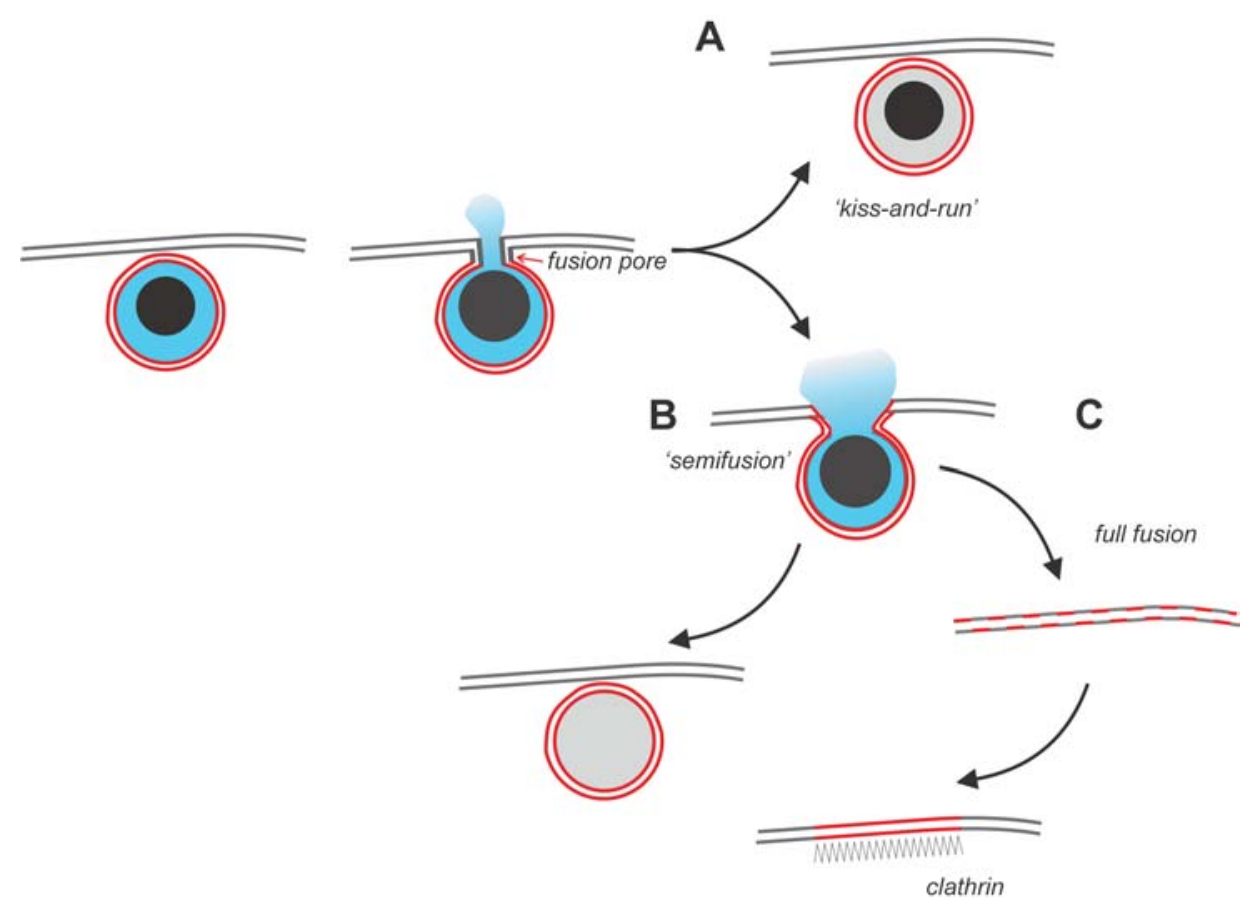

Fig. 11A-C. Kiss-and-run exocytosis (A), Semifusion (B) and full fusion (C). The plasma membrane (black) and the granule membrane (red) have been colour-coded to make it easier to follow the fate of the granule membrane after exocytosis. Following exocytosis, the granular membrane can either be retrieved in one piece $(\mathbf{A}, \mathbf{B})$ or after its complete integration into the plasma membrane via conventional clathrin-mediated endocytosis (C). Note that in A, low-molecular weight constituents of the granule lumen could be selectively released via the fusion pore (indicated by change in colour of the halo). In semifusion (B), both the peptide cargo and low-molecular weight substances can be fully or partially released

tions of secretory granules makes it tempting to speculate on the cell physiological mechanisms that underlie the secretory defect of Type 2 diabetes. It should be emphasized that the number of release-competent granules is not a fixed entity and the size of RRP can vary considerably within minutes (or even seconds) due to changes in, for example, the metabolic state and presence of stimulatory or inhibitory hormones and neurotransmitters $[71,80,97,116]$. Consequently, Type 2 diabetes might not be associated with any gross abnormalities of the intracellular granule distribution but rather result from defects in the preparation of granules for release. As we have attempted to illustrate here, reciprocal changes in the cytoplasmic concentrations of ATP and ADP affect a number of steps pertinent to the initiation and modulation of insulin secretion. Of particular relevance is the ability of ADP to control the release competence of the secretory granules. Type 2 diabetes associates with disturbances of glucose metabolism that impair the generation of ATP at the expense of ADP. These include defects of glycolysis manifested as substrate cycles of glucose metabolism [117] as well as impaired oxidative metabolism due to age-dependent accumulation of mito- chondrial mutations [118]. Obesity can also reduce insulin secretion via higher circulating concentrations of non-esterified fatty acids (NEFA). Chronic exposure to NEFA can be envisaged to impair ATP generation [119] by up-regulated expression of the mitochondrial uncoupling protein UCP2 synthesis [120] with resultant reduction in glucose-induced closure of the $\mathrm{K}_{\mathrm{ATP}^{-}}$ channel. Irrespective of whether beta-cell metabolism is impaired as a consequence of age, obesity or the combination of both, it is clear that failure of the beta cell to lower cytoplasmic ADP will affect secretion by interfering with both the triggering and amplifying actions of glucose on insulin secretion. In addition, there is evidence from animal models of human Type 2 diabetes (the GK-rat) that the impaired insulin secretory capacity correlates with reduced expression of proteins involved in the exocytotic process [121, 122]. Our observation that the assembly of a complex between the $\mathrm{Ca}^{2+}$-channels and the secretory granules is required for fast exocytosis [19, 75] further suggest that polymorphisms of genes encoding both the $\mathrm{Ca}^{2+}$ channel itself and the exocytotic proteins participating in the generation of the exocytotic core should be considered as potential diabetes genes. Indeed, there is evidence that a single nucleotide polymorphism in the syntaxin $1 \mathrm{~A}$ gene is correlated with age at onset and insulin requirement in Type 2 diabetic patients [123]. The functional effects of a given polymorphism are likely to be subtle and insignificant in the healthy beta cell. However, in a beta cell in which the metabolism is slightly compromised leading to decreased granule priming, they might exert more profound effects. Of course, the number of defects may not be limited to two but the greater number of such small defects that we combine, the graver the functional consequences become until eventually insulin secretion is insuffi- 
cient to maintain euglycaemia. This model is in keeping with the idea that most cases of Type 2 diabetes do not result from a single mutation but rather from an unfortunate combination of genetic traits that individually are of little consequence $[124,125,126]$.

The maintenance of insulin secretory capacity requires that the beta cell contains a sufficient number of release-competent granules (RRP) and that exocytosis is continuously balanced by the supply of new granules. It is not difficult to see how changes of the nature described above can account for the secretory abnormalities of Type 2 diabetes [116], which include the loss of first-phase (decrease in RRP) and reduction of secondphase insulin release (slow replenishment of new granules for release by mobilization of granules from the reserve pool). The concept that loss of functional pool of secretory granules contributes to the secretion defects associated with diabetes might seem at variance with the well-documented ability of arginine to elicit first phase insulin secretion in Type 2 diabetic patients. However, when the acute insulin responses to arginine were compared in diabetic and non-diabetic subjects, it became evident that they were reduced by more than $80 \%$ at all tested glucose concentrations [127]. This reduction can be accounted for by either reduced granule priming or the failure of the granules to assemble into a function complex with the $\mathrm{Ca}^{2+}$-channels. The small responses to arginine that remained observable in the diabetic patients, we attribute to a slow rate of granule priming taking place despite the impairment of glucose metabolism or granules that happened to be correctly situated in the vicinity of a $\mathrm{Ca}^{2+}$-channel. If this is so, then the question arises as to why first-phase glucose-induced insulin secretion is more severely affected than that elicited by arginine. This we attribute to the different modes by which glucose and arginine initiate electrical activity. Whereas glucose-induced electrical activity is secondary to accelerated beta-cell metabolism, arginine exerts a direct stimulatory effect via its electrogenic entry [128]. Accordingly, the impairment of glucose-induced insulin secretion results from the loss of triggering and amplifying actions, whereas only the latter is affected in the case of arginine. The concept that reduced granule priming contributes to the insulin secretory defect of Type 2 diabetes indicates that pharmacological agents that promote beta cell granule priming would have beneficial therapeutic effects. Proof of concept comes from the well-documented insulinotropic action of glucagon-like peptide 1 (GLP-1), which at least in mouse beta cells seems principally attributable to PKA-dependent stimulation of granule mobilisation and increase in the size of RRP [116]. A drug that mimics the action of GLP-1 on granule priming in the beta cell would therefore most likely represent a valuable addition to the spectrum of anti-diabetic drugs available.

Sources The review is based on the relevant literature published in the English language during the period 1990-2003, and seminal prior contributions. The sources available to the authors were integrated with sources identified through PubMed searches for "capacitance, exocytosis and insulin", "ion channels and insulin secretion" and "insulin and granule dynamics".

Acknowledgements. We thank F. Ashcroft for invaluable discussions on several topics covered by this review. We likewise gratefully acknowledge the contributions of our colleagues in Lund. Financial support was obtained from the Juvenile Diabetes Research Foundation, the Swedish Diabetes Association, the Novo Nordisk Foundation, the European Community and the Swedish Research Council.

\section{References}

1. Dean PM (1973) Ultrastructural morphometry of the pancreatic $\beta$-cell. Diabetologia 9:115-119

2. Olofsson CS, Göpel SO, Barg S et al. (2002) Fast insulin secretion reflects exocytosis of docked granules in mouse pancreatic B-cells. Pflugers Arch 444:43-51

3. Orci L, Malaisse-Lagae F, Ravazzola M, Amherdt M, Renold AE (1973) Exocytosis-endocytosis coupling in the pancreatic beta cell. Science 181:561-562

4. Orci L, Amherdt M, Malaisse-Lagae F, Rouiller C, Renold AE (1973) Insulin release by emiocytosis: demonstration with freeze-etching technique. Science 179:82-84

5. Wollheim CB, Sharp GW (1981) Regulation of insulin release by calcium. Physiol Rev 61:914-973

6. Ämmälä C, Ashcroft FM, Rorsman P (1993) Calciumindependent potentiation of insulin release by cyclic AMP in single $\beta$-cells. Nature 363:356-358

7. Neher E, Marty A (1982) Discrete changes of cell membrane capacitance observed under conditions of enhanced secretion in bovine adrenal chromaffin cells. Proc Natl Acad Sci USA 79:6712-6716

8. Wightman RM, Jankowski JA, Kennedy RT et al. (1991) Temporally resolved catecholamine spikes correspond to single vesicle release from individual chromaffin cells. Proc Natl Acad Sci USA 88:10754-10758

9. Steyer JA, Horstmann H, Almers W (1997) Transport, docking and exocytosis of single secretory granules in live chromaffin cells. Nature 388:474-478

10. Lang T, Wacker I, Steyer J et al. (1997) $\mathrm{Ca}^{2+}$-triggered peptide secretion in single cells imaged with green fluorescent protein and evanescent-wave microscopy. Neuron 18:857-863

11. Henquin JC, Meissner HP (1984) Significance of ionic fluxes and changes in membrane potential for stimulus-secretion coupling in pancreatic B-cells. Experientia 40:1043-1052

12. Ashcroft FM, Rorsman P (1989) Electrophysiology of the pancreatic $\beta$-cell. Prog Biophys Mol Biol 54:87-143

13. Valdeolmillos M, Santos RM, Contreras D, Soria B, Rosario LM (1989) Glucose-induced oscillations of intracellular $\mathrm{Ca}^{2+}$ concentration resembling bursting electrical activity in single mouse islets of Langerhans. FEBS Lett 259:19-23

14. Gilon P, Shepherd RM, Henquin JC (1993) Oscillations of secretion driven by oscillations of cytoplasmic $\mathrm{Ca}^{2+}$ as evidences in single pancreatic islets. J Biol Chem 268:22265-22268

15. Barbosa RM, Silva AM, Tome AR, Stamford JA, Santos RM, Rosario LM (1998) Control of pulsatile 5-HT/insulin secretion from single mouse pancreatic islets by intracellular calcium dynamics. J Physiol 510:135-143

16. Bergsten P (1995) Slow and fast oscillations of cytoplasmic $\mathrm{Ca}^{2+}$ in pancreatic islets correspond to pulsatile insulin release. Am J Physiol 268:E282-E287 
17. Göpel S, Kanno T, Barg S, Galvanovskis J, Rorsman P (1999) Voltage-gated and resting membrane currents recorded from B-cells in intact mouse pancreatic islets. J Physiol 521:717-728

18. Ämmälä C, Eliasson L, Bokvist K, Larsson O, Ashcroft FM, Rorsman P (1993) Exocytosis elicited by action potentials and voltage-clamp calcium currents in individual mouse pancreatic B-cells. J Physiol 472:665-688

19. Barg S, Ma X, Eliasson L et al. (2001) Fast exocytosis with few $\mathrm{Ca}^{2+}$ channels in insulin-secreting mouse pancreatic $\mathrm{B}$ cells. Biophys J 81:3308-3323

20. Wiser O, Trus M, Hernandez A et al. (1999) The voltage sensitive Lc-type $\mathrm{Ca}^{2+}$ channel is functionally coupled to the exocytotic machinery. Proc Natl Acad Sci USA 96:248-253

21. Curry DL, Bennett LL, Grodsky GM (1968) Dynamics of insulin secretion by the perfused rat pancreas. Endocrinology 83:572-584

22. Anello M, Gilon P, Henquin JC (1999) Alterations of insulin secretion from mouse islets treated with sulphonylureas: perturbations of $\mathrm{Ca}^{2+}$ regulation prevail over changes in insulin content. Br J Pharmacol 127:1883-1891

23. Bratanova-Tochkova TK, Cheng H, Daniel S et al. (2002) Triggering and augmentation mechanisms, granule pools, and biphasic insulin secretion. Diabetes 51 [Suppl 1]:S83-S90

24. Grodsky GM (1994) An update on implications of phsic insulin secretion. In: Flatt PR, Lenzen S (eds) Insulin secretion and pancreatic B-cell research. Smith Gordon, London, pp 421-430

25. Henquin JC (2000) Triggering and amplifying pathways of regulation of insulin secretion by glucose. Diabetes 49:1751-1760

26. Westerlund J, Bergsten P (2001) Glucose metabolism and pulsatile insulin release from isolated islets. Diabetes 50:1785-1790

27. Neher E (1998) Vesicle pools and $\mathrm{Ca}^{2+}$ microdomains: new tools for understanding their roles in neurotransmitter release. Neuron 20:389-399

28. Gentet LJ, Stuart GJ, Clements JD (2000) Direct measurement of specific membrane capacitance in neurons. Biophys J 79:314-320

29. Reetz A, Solimena M, Matteoli M, Folli F, Takei K, De Camilli P (1991) GABA and pancreatic beta-cells: colocalization of glutamic acid decarboxylase (GAD) and GABA with synaptic-like microvesicles suggests their role in GABA storage and secretion. Embo J 10:1275-1284

30. Kasai H (1999) Comparative biology of $\mathrm{Ca}^{2+}$-dependent exocytosis: implications of kinetic diversity for secretory function. Trends Neurosci 22:88-93

31. Borgonovo B, Cocucci E, Racchetti G, Podini P, Bachi A, Meldolesi J (2002) Regulated exocytosis: a novel, widely expressed system. Nat Cell Biol 4:955-962

32. Amatore C, Bouret Y, Travis ER, Wightman RM (2000) Adrenaline release by chromaffin cells: constrained swelling of the vesicle matrix leads to full fusion. Angew Chem Int Ed Engl 39:1952-1955

33. Smith PA, Duchen MR, Ashcroft FM (1995) A fluorimetric and amperometric study of calcium and secretion in isolated mouse pancreatic beta-cells. Pflugers Arch 430:808-818

34. Zhou Z, Misler S (1996) Amperometric detection of quantal secretion from patch-clamped rat pancreatic beta-cells. J Biol Chem 271:270-277

35. Smith PA, Proks P, Ashcroft FM (1999) Quantal analysis of 5-hydroxytryptamine release from mouse pancreatic betacells. J Physiol 521:651-664

36. Bokvist K, Holmqvist M, Gromada J, Rorsman P (2000) Compound exocytosis in voltage-clamped mouse pancreatic beta-cells revealed by carbon fibre amperometry. Pflugers Arch 439:634-645
37. Huang L, Shen H, Atkinson MA, Kennedy RT (1995) Detection of exocytosis at individual pancreatic beta cells by amperometry at a chemically modified microelectrode. Proc Natl Acad Sci USA 92:9608-9612

38. Aspinwall CA, Brooks SA, Kennedy RT, Lakey JR (1997) Effects of intravesicular $\mathrm{H}^{+}$and extracellular $\mathrm{H}^{+}$and $\mathrm{Zn}^{2+}$ on insulin secretion in pancreatic beta cells. J Biol Chem 272:31308-31314

39. Amatore C, Arbault S, Bonifas I, Bouret Y, Erard M, Guille M (2003) Dynamics of full fusion during vesicular exocytotic events: release of adrenaline by chromaffin cells. Chemphyschem 4:147-154

40. Travis ER, Wightman RM (1998) Spatio-temporal resolution of exocytosis from individual cells. Annu Rev Biophys Biomol Struct 27:77-103

41. Ohara-Imaizumi M, Nakamichi Y, Tanaka T, Katsuta H, Ishida H, Nagamatsu S (2002) Monitoring of exocytosis and endocytosis of insulin secretory granules in the pancreatic beta-cell line MIN6 using $\mathrm{pH}$-sensitive green fluorescent protein (pHluorin) and confocal laser microscopy. Biochem J 363:73-80

42. Bruns D, Jahn R (2002) Molecular determinants of exocytosis. Pflugers Arch 443:333-338

43. Jahn R, Lang T, Sudhof TC (2003) Membrane fusion. Cell 112:519-533

44. Lin RC, Scheller RH (2000) Mechanisms of synaptic vesicle exocytosis. Annu Rev Cell Dev Biol 16:19-49

45. Chapman ER (2002) Synaptotagmin: a $\mathrm{Ca}^{2+}$ sensor that triggers exocytosis? Nat Rev Mol Cell Biol 3:498-508

46. Shin OH, Rizo J, Sudhof TC (2002) Synaptotagmin function in dense core vesicle exocytosis studied in cracked PC12 cells. Nat Neurosci 5:649-656

47. Sugita S, Shin OH, Han W, Lao Y, Sudhof TC (2002) Synaptotagmins form a hierarchy of exocytotic $\mathrm{Ca}^{2+}$ sensors with distinct $\mathrm{Ca}^{2+}$ affinities. Embo J 21:270-280

48. Easom RA (2000) Beta-granule transport and exocytosis. Semin Cell Dev Biol 11:253-266

49. Lang J (1999) Molecular mechanisms and regulation of insulin exocytosis as a paradigm of endocrine secretion. Eur J Biochem 259:3-17

50. Martin F, Moya F, Gutierrez LM, Reig JA, Soria B (1995) Role of syntaxin in mouse pancreatic beta cells. Diabetologia 38:860-863

51. Martin F, Salinas E, Vazquez J, Soria B, Reig JA (1996) Inhibition of insulin release by synthetic peptides shows that the $\mathrm{H} 3$ region at the $\mathrm{C}$-terminal domain of syntaxin- 1 is crucial for $\mathrm{Ca}^{2+}$ - but not for guanosine $5^{\prime}$-[gamma-thio]triphosphate-induced secretion. Biochem J 320:201-205

52. Lang J, Fukuda M, Zhang H, Mikoshiba K, Wollheim CB (1997) The first C2 domain of synaptotagmin is required for exocytosis of insulin from pancreatic beta-cells: action of synaptotagmin at low micromolar calcium. Embo J 16:5837-5846

53. Brown H, Meister B, Deeney J et al. (2000) Synaptotagmin III isoform is compartmentalized in pancreatic beta-cells and has a functional role in exocytosis. Diabetes 49:383-391

54. Gut A, Kiraly CE, Fukuda M, Mikoshiba K, Wollheim CB, Lang J (2001) Expression and localisation of synaptotagmin isoforms in endocrine beta-cells: their function in insulin exocytosis. J Cell Sci 114:1709-1716

55. Bokvist K, Eliasson L, Ämmälä C, Renström E, Rorsman P (1995) Co-localization of L-type $\mathrm{Ca}^{2+}$ channels and insulin-containing secretory granules and its significance for the initiation of exocytosis in mouse pancreatic B-cells. EMBO J 14:50-57

56. Takahashi N, Kadowaki T, Yazaki Y, Miyashita Y, Kasai H (1997) Multiple exocytotic pathways in pancreatic beta cells. J Cell Biol 138:55-64 
57. Iezzi M, Escher G, Meda P et al. (1999) Subcellular distribution and function of Rab3A, B, C, and D isoforms in insulin-secreting cells. Mol Endocrinol 13:202-212

58. Geppert M, Goda Y, Stevens CF, Südhof TC (1997) The small GTP-binding protein Rab3A regulates a late step in synaptic vesicle fusion. Nature 387:810-814

59. Regazzi R, Ravazzola M, Iezzi M et al. (1996) Expression, localization and functional role of small GTPases of the Rab3 family in insulin-secreting cells. J Cell Sci 109:2265-2273

60. Coppola T, Perret-Menoud V, Luthi S, Farnsworth CC, Glomset JA, Regazzi R (1999) Disruption of Rab3-calmodulin interaction, but not other effector interactions, prevents Rab3 inhibition of exocytosis. Embo J 18:5885-5891

61. Yaekura K, Julyan R, Wicksteed BL et al. (2003) Insulin secretory deficiency and glucose intolerance in Rab3A null mice. J Biol Chem 278:9715-9721

62. Iezzi M, Regazzi R, Wollheim CB (2000) The Rab3-interacting molecule RIM is expressed in pancreatic beta-cells and is implicated in insulin exocytosis. FEBS Lett 474:66-70

63. Coppola T, Magnin-Luthi S, Perret-Menoud V, Gattesco S, Schiavo G, Regazzi R (2001) Direct interaction of the Rab3 effector RIM with $\mathrm{Ca}^{2+}$ channels, SNAP-25, and synaptotagmin. J Biol Chem 276:32756-32762

64. Schoch S, Castillo PE, Jo T et al. (2002) RIM1alpha forms a protein scaffold for regulating neurotransmitter release at the active zone. Nature 415:321-326

65. Ozaki N, Shibasaki T, Kashima Y et al. (2000) cAMP-GEFII is a direct target of cAMP in regulated exocytosis. Nat Cell Biol 2:805-811

66. Eliasson L, Ma X, Renström E et al. (2003) SUR1 Regulates PKA-independent cAMP-induced Granule Priming in Mouse Pancreatic B-cells. J Gen Physiol 121:181-197

67. Xu T, Rammner B, Margittai M, Artalejo AR, Neher E, Jahn R (1999) Inhibition of SNARE complex assembly differentially affects kinetic components of exocytosis. Cell 99:713-722

68. Rettig J, Neher E (2002) Emerging roles of presynaptic proteins in $\mathrm{Ca}^{++}$-triggered exocytosis. Science 298:781-785

69. Grodsky G, Landahl H, Curry D, Bennett L (1970) A twocompartmental model for insulin secretion. Adv Metab Disord 1[Suppl 1]:45-50

70. O'Connor MD, Landahl H, Grodsky GM (1980) Comparison of storage- and signal-limited models of pancreatic insulin secretion. Am J Physiol 238:R378-389

71. Renström E, Eliasson L, Rorsman P (1997) Protein kinase A-dependent and -independent stimulation of exocytosis by cAMP in mouse pancreatic B-cells. J Physiol 502:105-118

72. Gromada J, Hoy M, Renström E et al. (1999) CaM kinase II-dependent mobilization of secretory granules underlies acetylcholine-induced stimulation of exocytosis in mouse pancreatic B-cells. J Physiol 518:745-759

73. Rorsman P, Eliasson L, Renstrom E, Gromada J, Barg S, Göpel S (2000) The cell physiology of biphasic insulin secretion. News Physiol Sci 15:72-77

74. Eddlestone GT, Oldham SB, Lipson LG, Premdas FH, Beigelman PM (1985) Electrical activity, cAMP concentration, and insulin release in mouse islets of Langerhans. Am J Physiol 248:C145-C153

75. Barg S, Eliasson L, Renström E, Rorsman P (2002) A subset of 50 secretory granules in close contact with L-type $\mathrm{Ca}^{2+}$ channels accounts for first-phase insulin secretion in mouse beta-cells. Diabetes 51 [Suppl 1]:S74-S82

76. Dean PM, Matthews EK (1970) Glucose-induced electrical activity in pancreatic islet cells. J Physiol 210:255-264

77. Henquin JC, Ishiyama N, Nenquin M, Ravier MA, Jonas JC (2002) Signals and pools underlying biphasic insulin secretion. Diabetes 51 [Suppl 1]:S60-S67
78. Daniel S, Noda M, Straub SG, Sharp GW (1999) Identification of the docked granule pool responsible for the first phase of glucose-stimulated insulin secretion. Diabetes 48:1686-1690

79. Ohara-Imaizumi M, Nakamichi Y, Tanaka T, Ishida H, Nagamatsu S (2002) Imaging exocytosis of single insulin secretory granules with evanescent wave microscopy: distinct behavior of granule motion in biphasic insulin release. J Biol Chem 277:3805-3808

80. Renstrom E, Ding WG, Bokvist K, Rorsman P (1996) Neurotransmitter-induced inhibition of exocytosis in insulin-secreting beta cells by activation of calcineurin. Neuron 17:513-522

81. Takahashi N, Kadowaki T, Yazaki Y, Ellis-Davies GC, Miyashita Y, Kasai H (1999) Post-priming actions of ATP on $\mathrm{Ca}^{2+}$-dependent exocytosis in pancreatic beta cells. Proc Natl Acad Sci USA 96:760-765

82. Ekholm R, Ericson LE, Lundquist I (1971) Monoamines in the pancreatic islets of the mouse. Subcellular localization of 5-hydroxytryptamine by electron microscopic autoradiography. Diabetologia 7:339-348

83. Eliasson L, Proks P, Ämmälä C et al. (1996) Endocytosis of secretory granules in mouse pancreatic beta-cells evoked by transient elevation of cytosolic calcium. J Physiol 493:755-767

84. Takahashi N, Kishimoto T, Nemoto T, Kadowaki T, Kasai $\mathrm{H}$ (2002) Fusion pore dynamics and insulin granule exocytosis in the pancreatic islet. Science 297:1349-1352

85. Albillos A, Dernick G, Horstmann H, Almers W, Alvarez de Toledo G, Lindau M (1997) The exocytotic event in chromaffin cells revealed by patch amperometry. Nature 389:509-512

86. Pouli AE, Emmanouilidou E, Zhao C, Wasmeier C, Hutton JC, Rutter GA (1998) Secretory-granule dynamics visualized in vivo with a phogrin-green fluorescent protein chimaera. Biochem J 333:193-199

87. Tsuboi T, Zhao C, Terakawa S, Rutter GA (2000) Simultaneous evanescent wave imaging of insulin vesicle membrane and cargo during a single exocytotic event. Curr Biol 10:1307-1310

88. Barg S, Olofsson CS, Schriever-Abeln J et al. (2002) Delay between fusion pore opening and peptide release from large dense-core vesicles in neuroendocrine cells. Neuron 33:287-299

89. Watkins S, Geng X, Li L, Papworth G, Robbins PD, Drain P (2002) Imaging secretory vesicles by fluorescent protein insertion in propeptide rather than mature secreted peptide. Traffic 3:461-471

90. Varadi A, Ainscow EK, Allan VJ, Rutter GA (2002) Involvement of conventional kinesin in glucose-stimulated secretory granule movements and exocytosis in clonal pancreatic beta-cells. J Cell Sci 115:4177-4189

91. Amatore C, Bouret Y, Travis ER, Wightman RM (2000) Interplay between membrane dynamics, diffusion and swelling pressure governs individual vesicular exocytotic events during release of adrenaline by chromaffin cells. Biochimie 82:481-496

92. Tsuboi T, Rutter GA (2003) Multiple forms of "kiss-andrun" exocytosis revealed by evanescent wave microscopy. Curr Biol 13:563-567

93. Hutton JC, Peshavaria M, Tooke NE (1983) 5-Hydroxytryptamine transport in cells and secretory granules from a transplantable rat insulinoma. Biochem J 210:803-810

94. Hutton JC, Penn EJ, Peshavaria M (1983) Low-molecularweight constituents of isolated insulin-secretory granules. Bivalent cations, adenine nucleotides and inorganic phosphate. Biochem J 210:297-305 
95. Maechler P, Wollheim CB (1999) Mitochondrial glutamate acts as a messenger in glucose-induced insulin exocytosis. Nature 402:685-689

96. Ericson LE, Hekanson R, Lundquist I (1977) Accumulation of dopamine in mouse pancreatic B-cells following injection of L-DOPA. Localization to secretory granules and inhibition of insulin secretion. Diabetologia 13: $117-124$

97. Eliasson L, Renström E, Ding WG, Proks P, Rorsman P (1997) Rapid ATP-dependent priming of secretory granules precedes $\mathrm{Ca}^{2+}$-induced exocytosis in mouse pancreatic B-cells. J Physiol 503:399-412

98. Somers G, Blondel B, Orci L, Malaisse WJ (1979) Motile events in pancreatic endocrine cells. Endocrinology 104:255-264

99. Bertrand G, Ishiyama N, Nenquin M, Ravier MA, Henquin JC (2002) The elevation of glutamate content and the amplification of insulin secretion in glucose-stimulated pancreatic islets are not causally related. J Biol Chem 277:32883-32891

100. Aizawa T, Sato Y, Komatsu M, Hashizume K (1992) ATPsensitive $\mathrm{K}^{+}$channel-independent, insulinotropic action of glucose in the B-cells. Endocr Regul 26:159-162

101. Baukrowitz T, Fakler B (2000) KATP channels gated by intracellular nucleotides and phospholipids. Eur J Biochem 267:5842-5848

102. Ashcroft FM, Gribble FM (1999) ATP-sensitive $\mathrm{K}^{+}$channels and insulin secretion: their role in health and disease. Diabetologia 42:903-919

103. Bryan J, Aguilar-Bryan L (1999) Sulfonylurea receptors: $\mathrm{ABC}$ transporters that regulate ATP-sensitive $\mathrm{K}^{+}$channels. Biochim Biophys Acta 1461:285-303

104. Nichols CG, Koster JC (2002) Diabetes and insulin secretion: whither KATP? Am J Physiol Endocrinol Metab 283:E403-E412

105. Malaisse WJ, Herchuelz, A (1982) Nutritional regulation of $\mathrm{K}^{+}$conductance: an unsettled aspect of pancreatic $\mathrm{B}$ cell physiology. In: Litwack G (ed.) Biochemical actions of hormones. Academic Press, New York, pp 69-92

106. Detimary P, Dejonghe S, Ling Z, Pipeleers D, Schuit F, Henquin JC (1998) The changes in adenine nucleotides measured in glucose-stimulated rodent islets occur in beta cells but not in alpha cells and are also observed in human islets. J Biol Chem 273:33905-33908

107. Olsen HL, Hoy M, Zhang W et al. (2003) Phosphatidylinositol 4-kinase serves as a metabolic sensor and regulates priming of secretory granules in pancreatic beta cells. Proc Natl Acad Sci USA 100:5187-5192

108. Ghosh A, Ronner P, Cheong E, Khalid P, Matschinsky FM (1991) The role of ATP and free ADP in metabolic coupling during fuel-stimulated insulin release from islet beta-cells in the isolated perfused rat pancreas. J Biol Chem 266:22887-22892

109. Barg S, Huang P, Eliasson L et al. (2001) Priming of insulin granules for exocytosis by granular $\mathrm{Cl}^{-}$uptake and acidification. J Cell Sci 114:2145-2154

110. Thevenod F (2002) Ion channels in secretory granules of the pancreas and their role in exocytosis and release of secretory proteins. Am J Physiol Cell Physiol 283:C651-C672

111. Galli T, Haucke V (2001) Cycling of synaptic vesicles: how far? How fast! Sci STKE 2001:RE1
112. Jarousse N, Kelly RB (2001) Endocytotic mechanisms in synapses. Curr Opin Cell Biol 13:461-469

113. Taraska JW, Perrais D, Ohara-Imaizumi M, Nagamatsu S, Almers W (2003) Secretory granules are recaptured largely intact after stimulated exocytosis in cultured endocrine cells. Proc Natl Acad Sci USA 100:2070-2075

114. Neves G, Lagnado L (1999) The kinetics of exocytosis and endocytosis in the synaptic terminal of goldfish retinal bipolar cells. J Physiol 515:181-202

115. Hosker JP, Rudenski AS, Burnett MA, Matthews DR, Turner RC (1989) Similar reduction of first- and secondphase B-cell responses at three different glucose levels in type II diabetes and the effect of gliclazide therapy. Metabolism 38:767-772

116. Gromada J, Holst JJ, Rorsman P (1998) Cellular regulation of islet hormone secretion by the incretin hormone glucagon-like peptide 1. Pflugers Arch 435:583-594

117. Efendic S, Wajngot A, Vranic M (1985) Increased activity of the glucose cycle in the liver: early characteristic of type 2 diabetes. Proc Natl Acad Sci USA 82:2965-2969

118. Maechler P, Wollheim CB (2001) Mitochondrial function in normal and diabetic beta-cells. Nature 414:807-812

119. Chan CB, De Leo D, Joseph JW et al. (2001) Increased uncoupling protein-2 levels in beta-cells are associated with impaired glucose-stimulated insulin secretion: mechanism of action. Diabetes 50:1302-1310

120. Lameloise N, Muzzin P, Prentki M, AssimacopoulosJeannet F (2001) Uncoupling protein 2: a possible link between fatty acid excess and impaired glucose-induced insulin secretion? Diabetes 50:803-809

121. Nagamatsu S, Nakamichi Y, Yamamura C et al. (1999) Decreased expression of t-SNARE, syntaxin 1, and SNAP-25 in pancreatic beta-cells is involved in impaired insulin secretion from diabetic GK rat islets: restoration of decreased t-SNARE proteins improves impaired insulin secretion. Diabetes 48:2367-2373

122. Zhang W, Khan A, Ostenson CG, Berggren PO, Efendic S, Meister B (2002) Down-regulated expression of exocytotic proteins in pancreatic islets of diabetic GK rats. Biochem Biophys Res Commun 291:1038-1044

123. Tsunoda K, Sanke T, Nakagawa T, Furuta H, Nanjo K (2001) Single nucleotide polymorphism (D68D, T to C) in the syntaxin 1A gene correlates to age at onset and insulin requirement in Type II diabetic patients. Diabetologia 44:2092-2097

124. Bell GI, Polonsky KS (2001) Diabetes mellitus and genetically programmed defects in beta-cell function. Nature 414:788-791

125. McCarthy M, Menzel S (2001) The genetics of type 2 diabetes. Br J Clin Pharmacol 51:195-199

126. Froguel P, Velho G (2001) Genetic determinants of type 2 diabetes. Recent Prog Horm Res 56:91-105

127. Ward WK, Bolgiano DC, McKnight B, Halter JB, Porte D Jr (1984) Diminished B cell secretory capacity in patients with noninsulin-dependent diabetes mellitus. J Clin Invest 74:1318-1328

128. Smith PA, Sakura H, Coles B, Gummerson N, Proks P, Ashcroft FM (1997) Electrogenic arginine transport mediates stimulus-secretion coupling in mouse pancreatic betacells. J Physiol 499:625-635 